\title{
Gondwana break-up related magmatism in the Falkland Islands
}

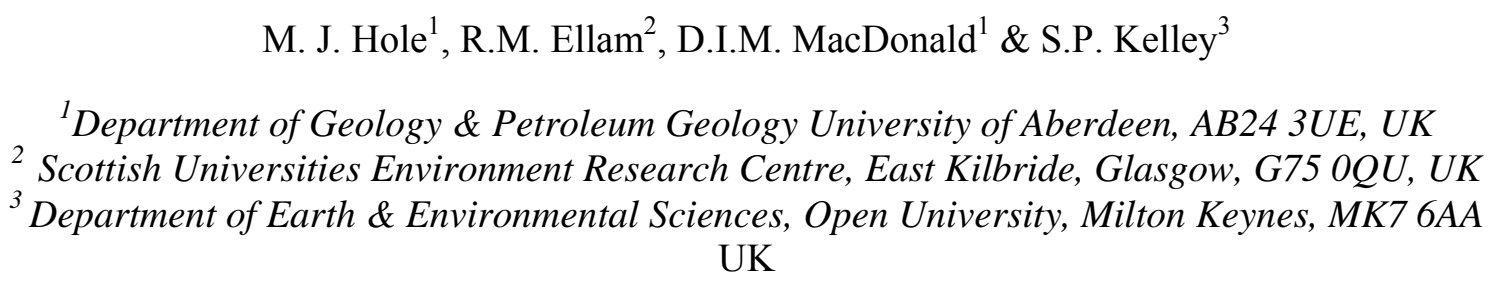

Jurassic dykes (c. $182 \mathrm{Ma}$ ) are widespread across the Falkland Islands and exhibit considerable geochemical variability. Orthopyroxene-bearing NW-SE oriented quartz-tholeiite dykes underwent fractional crystallization $>1 \mathrm{GPa}$, and major element constraints suggest that they were derived by melting of pyroxenite-rich source. They have $\varepsilon \mathrm{Nd}_{182}$ in the range -6 to -11 and ${ }^{87} \mathrm{Sr}^{86} \mathrm{Sr}_{182}>0.710$ and therefore require an old lithospheric component in their source. A suite of basaltic-andesites and andesites exhibit geochemical compositions transitional between Ferrar and Karoo magma types, and are similar to those seen in the KwaZulu-Natal region of southern Africa and the Theron Mountains of Antarctica. Olivine-phyric intrusions equilibrated at $<0.5$ GPa, and have isotopic compositions $\left(\varepsilon \mathrm{Nd}_{182}\right.$ 1.6-3.6 and ${ }^{87} \mathrm{Sr} /{ }^{86} \mathrm{Sr}_{182}$ 0.7036-0.7058) that require limited interaction with old continental lithosphere. A suite of plagioclase-phyric intrusions with ${ }^{87} \mathrm{Sr} /{ }^{86} \mathrm{Sr}_{182}$ c. 0.7035 and $\varepsilon \mathrm{Nd}_{182}$ c. +4 , and low $\mathrm{Th} / \mathrm{Ta}$ and $\mathrm{La} / \mathrm{Ta}$ ratios (c. 1 and c. 15 respectively) also largely escaped interaction with the lithosphere. These isotopically depleted intrusions were probably emplaced synchronously with Gondwana fragmentation and the formation of new oceanic lithosphere. Estimates of mantle potential temperature from olivine equilibration temperatures do not provide unequivocal evidence for the presence of a plume thermal anomaly beneath the Falkland Islands at $182 \mathrm{Ma}$. 
25 The Early Jurassic (c. $180 \mathrm{Ma}$ ) Karoo and Ferrar large igneous provinces (LIP) were associated with Gondwana break-up. Igneous rocks of the Karoo province occur predominantly in South Africa but extend into Dronning Maud Land (Antarctica) with the main phase of activity taking place in the interval 182-183 Ma (Svensen et al. 2012). The Ferrar Province, which is contemporaneous with the magmatism in the Karoo province (Burgess et al. 2015), is typified by the low $\mathrm{TiO}_{2}$ Jurassic igneous rocks of the Transantarctic Mountains and Tasmania (Hergt et al. 1989; Fleming et al. 1995). It has also been established that the Karoo and Ferrar provinces have areas of geographical overlap, most notably in the KwaZulu area of South Africa (Sweeney et al. 1994; Riley et al. 2006) and in the Theron Mountains of Antarctica (Brewer et al. 1992). In the latter, at least four suites of low $\mathrm{TiO}_{2}$ igneous rocks have been recognized, and it has been suggested that there is a transition from one province to the other rather, than a strict geographical delineation between the two provinces (Brewer et al. 1992). fragmentation, plate reconstructions place the Falkland Islands on the extension of the Cape Fold Belt of South Africa, on the eastern flank of the Lebombo Rift (Fig. 1; Macdonald et al. 2003; Stone et al. 2008; 2009; Richards et al. 2013). Post-180 Ma, there was major reorganization of crustal blocks in Patagonia, the Falklands Plateau and west Antarctica, which included the clockwise rotation of the Falklands crustal block in an overall extensional regime. The $180^{\circ}$ rotation of the Falkland Islands from their pre-180 Ma position was complete by 165 Ma (Macdonald et al. 2003), and by this time the islands had migrated to the west along the extension of the Aghulas Fracture zone to a position well to the west of the WTJ (Richards et al. 2013). Consequently, the Falkland Islands may have been very close to the focus of break-up related magmatism, and it is logical to assume that the geochemical composition of any igneous rocks found in the islands should reflect the diversity of magmatism in the Jurassic Gondwana 
51 LIP as a whole. In this paper, new data are presented that show that the dykes and minor 52 intrusions of the Falkland Islands exhibit variability in mineralogy, major element, trace element 53 and $\mathrm{Sr}-, \mathrm{Nd}-$ and $\mathrm{Pb}$-isotopic compositions that is nearly as large as that seen in the entire 54 Jurassic Gondwana LIP, even though the Falkland Islands themselves represent only an 55 extremely small area compared to the total distribution of Jurassic igneous rocks of the region. 56 Intrusions with major and trace element characteristics most similar the Ferrar dolerites of the 57 Transantarctic Mountain are juxtaposed with intrusions which are nearly identical to some 58 Karoo basalts of South Africa and Antarctica.

\section{$59 \quad$ Falkland Islands Dyke Swarm}

Dolerite dykes, mostly of Jurassic age, are widespread in West Falkland and rather sparse in East Falkland (Fig. 2; Greenway 1972; Mussett \& Taylor 1994; Thistlewood et al. 1997; Mitchell et al. 1999; Stone et al. 2008, 2009; Richards et al. 2013). Distinct sub-swarms of dykes have been recognized based on azimuth of exposed intrusions and aeromagnetic anomalies (Mitchell et al. 1999; Stone et al. 2009). Prominent dolerite dykes, tens of metres wide and oriented NE-SW, are present in both West and East Falkland and are reversely magnetized. This suite corresponds to the N-S suite of Mitchell et al. (1999), and is of Jurassic age (c. 178-190 Ma; Mussett \& Taylor 1994; Stone et al. 2009) although the older of these ages were generated by the Ar-Ar method on whole-rock samples and have large errors (e.g R1790 190 \pm 4 Ma; Mussett \& Taylor 1994). E-W oriented olivine-dolerite dykes occur locally in the south of West Falkland, and they form part of a larger suite of intrusions that Stone et al. (2009) suggest has a partially radial disposition. In addition, Richards et al. (2013) noted that there is a suite of about 40, N-S oriented magnetic anomalies, that may represent intrusions, and these occur across the entire Falkland Islands. Exposed examples from Teal Creek and Peat Banks (Fig. 2) yield ${ }^{40} \mathrm{Ar} /{ }^{39} \mathrm{Ar}$ ages in the range 133-138 Ma and these dykes are likely to be members of the Etendeka suite of south-western Africa (Stone et al. 2009; Richards et al. 2013). During

76 the current study, ${ }^{40} \mathrm{Ar} /{ }^{39} \mathrm{Ar}$ step-heating analysis was carried-out on separated plagioclase 
feldspar phenocrysts from three samples, but only one of these yielded useful information. Sample WI-5, a NE-SW oriented dyke from Weddell Island (Fig. 2), which is also within the area of the radial swarm identified by Richards et al. (2013), contains abundant plagioclase phenocrysts, and yielded a precise age of $182.3 \pm 1.5 \mathrm{Ma}$ (Fig. 3). This confirms a Jurassic age for some of the Falkland Islands intrusions, and it is within error of the $178.6 \pm 4.9 \mathrm{Ma}$ determined by Stone et al. (2008) for an aphyric NE-SW dyke from Port Sussex Creek, East Falkland (Fig. 2).

Selected major and trace element abundances versus weight $\% \mathrm{MgO}$ for 139 intrusions from the Falkland Islands, including 109 from this study and 30 from Mitchell et al. (1999), are shown in Fig. 4 and representative analyses are given in Table 1. Mitchell et al. (1999) divided the intrusions of the Falkland Islands into two main N-S and E-W suites based on azimuth, field occurrence, petrography, mineral chemistry and whole-rock geochemical data. A subsidiary three magma types were also tentatively identified by Mitchell et al. (1999), including 'evolved N-S', Lively Island and Mount Alice types. The reassessment of the spatial distribution, orientation and age of the dyke swarms by Stone et al. (2009) and Richards et al. (2013), along with the much enlarged data set for the igneous rocks of the Falkland Islands generated for this study, now allows the identification of five individual geochemical types of intrusions. The criteria used to separate the different groups of intrusions are given in Table 2 and are illustrated in Figs 4 to 9. A description of each suite is given below.

Port Sussex Creek-type intrusions (PST). All the N-S dykes of Mitchell et al. (1999) are included in this suite of intrusions, with the exception of the 'evolved type' described by Mitchell et al. (1999) which will be discussed under the Dyke Island Type (samples NHF17 and NGF15). PST intrusions are widely distributed across both East Falkland and West Falkland, all are sub-vertical with an azimuth of NE-SW, and they are consistently between 8 and $10 \mathrm{~m}$ in thickness. A typical example occurs at Port Sussex Creek, East Falkland, (MHF1; Table 1, Fig. 2), and is an $8 \mathrm{~m}$ wide, sub-vertical, medium-grained, spheroidally-weathering dolerite dyke with 

an azimuth of $45^{\circ}$ (NE-SW) and an age of 178.6 \pm 4.9 Ma (Stone et al. 2008). The texture is equigranular and intersertal. Pyroxene is enstatite $\left(\mathrm{En}_{70} \mathrm{Wo}_{4} \mathrm{Fs}_{26}\right)$, pigeonite $\left(\mathrm{En}_{51} \mathrm{Wo}_{13} \mathrm{Fs}_{36}\right)$ and augite (Fig. 5) and the feldspar is labradorite $\left(\mathrm{An}_{70}\right)$. All PST intrusions contain both augite and pigeonite, with more mafic samples containing orthopyroxene. Olivine $\left(\mathrm{Fo}_{50-71}\right)$ is rare in this suite of rocks and is restricted to intrusions with $\mathrm{Mg \#}>58$ (e.g. FAR1503 and NGF16; Table 1, Fig. 4). Whole-rock $\mathrm{MgO}$ contents vary from 5.9-9.5 wt\% $(\mathrm{Mg} \# 50-62)$ and $\mathrm{SiO}_{2}(53-55 \mathrm{wt} \%)$ is higher for a given $\mathrm{MgO}$ concentration than any of the other Falkland Islands intrusions (Fig. 4). The PST intrusions are characterized by low $\mathrm{CaO}(8.1-9.8 \mathrm{wt} \%)$ for a given $\mathrm{MgO}$ content compared to other Falkland Islands intrusions. $\mathrm{TiO}_{2}$ abundances $(0.9-1.2 \mathrm{wt} \%)$ are typical of the low $\mathrm{TiO}_{2}$ Gondwana break-up related LIPs of the southern hemisphere and distinguishes them from the high $\mathrm{TiO}_{2}(>2.5 \mathrm{wt} \%)$ suite of break-up related magmas (e.g. Brewer et al. 1992). Abundances of $\mathrm{Cr}$ are unusually high (up to 648ppm) for samples with $\mathrm{SiO}_{2}$ in their range, and are reflected in the high $\mathrm{Cr}$ content of orthopyroxene. Abundances of $\mathrm{Nb}$ and $\mathrm{Y}$ are restricted to 2-5 and 19-23ppm respectively. PST intrusions are LREE enriched (Fig. 6) with $[\mathrm{La} / \mathrm{Yb}]_{\mathrm{N}}$ in the range 3.2-3.9 and samples lack any significant $\mathrm{Eu}$ anomaly $\left(\mathrm{Eu} / \mathrm{Eu}^{*} 0.89-0.97\right) . \mathrm{La} / \mathrm{Ta}$ and $\mathrm{Th} / \mathrm{Ta}$ are the highest of any of the Falkland Islands samples analysed (44-52 and 5.9-8.6 respectively), and consequently, on ORB-normalized multi-element diagrams (Fig. 7), samples exhibit a marked trough in the abundances of $\mathrm{Ta}$ and $\mathrm{Nb}$ relative to $\mathrm{Th}, \mathrm{U}, \mathrm{K}$ and $\mathrm{La} .[\mathrm{Ta} / \mathrm{Yb}]_{\mathrm{N}}$ is in the range 2.0 to 2.6 , the lowest values for any of the Falkland Islands intrusions. Ti/Zr and $\mathrm{P} / \mathrm{Zr}$ (55-60 and 4.5-6.3 respectively) are such that all PST intrusions exhibit a minor trough at $\mathrm{Ti}$ and $\mathrm{P}$ relative to adjacent elements on ORB-normalized diagrams. $\varepsilon \mathrm{Nd}_{182}$ varies from -5.5 to 11.0 and is accompanied by radiogenic Sr-isotopic compositions $\left({ }^{87} \mathrm{Sr}^{86} \mathrm{Sr}_{182} 0.7070-0.7134\right)$, although Sr-Nd isotope covariations are rather scattered (Fig. 8). Pb-isotopic compositions form an array that is close to the Geochron $\left({ }^{207} \mathrm{~Pb} /{ }^{204} \mathrm{~Pb}=15.55-15.65\right)$, and extends to ${ }^{206} \mathrm{~Pb} /{ }^{204} \mathrm{~Pb}$ ratios of up to $18.40 .{ }^{207} \mathrm{~Pb} /{ }^{204} \mathrm{~Pb}$ exhibits a negative correlation with $\varepsilon \mathrm{Nd}_{182}$ for PST intrusions (Fig. 8). Marked negative correlations between $1 / \mathrm{Sr}$ and ${ }^{87} \mathrm{Sr} /{ }^{86} \mathrm{Sr}_{182}, \varepsilon \mathrm{Nd}_{182}$ and $\mathrm{Th} / \mathrm{Ta}$ and a 
positive correlation between $\mathrm{MgO}$ and $\varepsilon \mathrm{Nd}_{182}$ (Fig. 9) suggests that PST dykes underwent interaction with a high ${ }^{87} \mathrm{Sr} /{ }^{86} \mathrm{Sr}_{182}(>0.714)$, low $\varepsilon \mathrm{Nd}_{182}(<-12)$ component that had $\mathrm{Th} / \mathrm{Ta}>9$, and that interaction was concomitant with crystallization

E-W intrusions. The E-W samples reported by Mitchell et al. (1999) are from a single intrusion, approximately $10 \mathrm{~m}$ wide, which can be traced for more than $30 \mathrm{~km}$ from Fox Bay West to Queen Charlotte Bay (Fig. 2). These samples are generally medium-grained olivine-phyric dolerites $\left(\mathrm{Fo}_{82}\right.$ at $11 \mathrm{wt} \% \mathrm{MgO}$ in the whole-rock), the only pyroxene present being augite (Fig. 5). During the current study, intrusions with similar petrographic and mineralogical characteristics were found around South Harbour and on Weddell Island (Fig. 2). E-W intrusions are distinguished from the PST (Fig. 10) by their lower $\mathrm{SiO}_{2}$ contents $(48-52 \mathrm{wt} \%)$ and higher $\mathrm{Ti} / \mathrm{Zr}(80-95)$ for a similar range in $\mathrm{TiO}_{2}$, and $\mathrm{MgO}$ content (1.0-1.4 and 4.8-11.4wt $\%$ respectively). E-W intrusions have $[\mathrm{La} / \mathrm{Yb}]_{\mathrm{N}}$ in the range 2.1-4.0 (Fig. 6) and no appreciable Eu anomaly $\left(\mathrm{Eu} / \mathrm{Eu}^{*} 0.89-1.0\right) .[\mathrm{Ta} / \mathrm{Yb}]_{\mathrm{N}}$ ratios are in the range 2.8 to 4.7 , and all samples exhibit a negative $\mathrm{Nb}$, Ta trough relative to the LILE ( $\mathrm{La} / \mathrm{Ta}, 16-27, \mathrm{Th} / \mathrm{Ta} 2.2-2.8$ ) but this is not as pronounced as that for the PST intrusions (Fig. 7). E-W intrusions have isotopic compositions that are close to, or slightly depleted relative to the Chondritic Uniform Reservoir $\left(\varepsilon \mathrm{Nd}_{182}=-0.4\right.$ to $\left.3.0 ;{ }^{87} \mathrm{Sr}^{86} \mathrm{Sr}_{182}=0.7036-0.7058\right)$ and have $\mathrm{Pb}$-isotopic compositions that lie just above the NHRL (Fig. 8).

Lively Island intrusion. A single 30m thick intrusion which is exposed on Lively Island has noticeably lower $\mathrm{TiO}_{2}$ for a given $\mathrm{MgO}$ content than any other of the Falklands Islands intrusions $\left(\mathrm{TiO}_{2}=0.8 \mathrm{wt} \%\right.$ at $\left.6 \mathrm{wt} \% \mathrm{MgO}\right)$ and the data falls close to the compositional trend for low $\mathrm{TiO}_{2}$ Ferrar dolerites from the Transantarctic Mountains (Fig. 11). Characteristic mineralogical features are the presence of sparse, $\mathrm{Mg}$-rich biotite and rare Ca-poor groundmass pyroxene (Fig. 5). The intrusion has a LREE-enriched REE profile $\left([\mathrm{La} / \mathrm{Yb}]_{\mathrm{N}}=3.2\right.$; Fig. 6$)$ which lacks a significant negative Eu anomaly $\left(\mathrm{Eu} / \mathrm{Eu}^{*}=0.87\right) . \mathrm{La} / \mathrm{Ta}$ and $\mathrm{Th} / \mathrm{Ta}(20.4$ and 3.2 respectively) are similar to E-W intrusions and considerably lower than for PST intrusions 
(Table 2). The Lively Island intrusion contains radiogenic $\mathrm{Nd}$ and unradiogenic $\mathrm{Sr}\left(\varepsilon \mathrm{Nd}_{182}-0.5\right.$, ${ }^{87} \mathrm{Sr} /{ }^{86} \mathrm{Sr}_{182}$ c. 0.7060$)$ compared to PST intrusions.

Dyke Island Type (DIT). The greatest concentration of DIT intrusions is on aptly-named Dyke Island (Fig. 2). Sample WI-5 which yielded the Ar-Ar age of 182.3 \pm 1.5 Ma which crops out on Weddell Island (Fig. 2) is of this type. In addition, the evolved N-S samples described by Mitchell et al. (1999) are of this type (e.g. NHF17; Fig. 2). Intrusions are generally $<50 \mathrm{~cm}$ thick, they may contain abundant plagioclase \pm augite phenocrysts (samples WI-5, MHF14.9 and FAR338; Fig. 5), or more commonly they are medium- to fined-grained aphyric basalticandesites and andesites with rare rhyolite sheets occurring locally. DIT intrusions represent an expanded fractionation series with $\mathrm{MgO}$ varying from 5.6 to $<0.1 \mathrm{wt} \%$, over a range of 51 $75 \mathrm{wt} \% \mathrm{SiO}_{2} . \mathrm{Ti} / \mathrm{Zr}$ is in the range $32-55$ for samples with $4.0-5.6 \mathrm{wt} \% \mathrm{MgO}$, and for samples with $<1 \mathrm{wt} \% \mathrm{MgO}, \mathrm{Ti} / \mathrm{Zr}$ falls to $<5$ (Fig. 4). All DIT intrusions have higher concentrations of the incompatible elements $\mathrm{Zr}, \mathrm{Nb}$ and $\mathrm{Y}$ than any of the other intrusions from the Falkland Islands, and exhibit strong positive linear correlations between these elements. On a plot of $\mathrm{TiO}_{2}$ versus $\mathrm{MgO}$ (Figs 4 \& 11) DIT intrusions can be divided into three distinct series; i) a low $\mathrm{TiO}_{2}$ series which forms and extension of the data array for PST intrusions; ii) a high $\mathrm{TiO}_{2}$ series with $\mathrm{MgO}$ in the range $2.5-4.0 \mathrm{wt} \% \mathrm{MgO}$ with $\mathrm{TiO}_{2}>1.7 \mathrm{wt} \%$; and iii) acid intrusions with $<2 \mathrm{wt} \%$ $\mathrm{MgO}$.

DIT intrusions are LREE-enriched $\left([\mathrm{La} / \mathrm{Yb}]_{\mathrm{N}}=4.1-6.6\right.$; Fig. 6) and exhibit stepwise increases in both LREE and HREE abundances with decreasing $\mathrm{MgO}$ with the most evolved sample (MHF41.3, 0.06wt\% MgO) having $\mathrm{La}_{\mathrm{N}}=190$ and $\mathrm{Yb}_{\mathrm{N}}=44$. The development of a progressively larger negative Eu anomaly $\left(\mathrm{Eu} / \mathrm{Eu}^{*} 0.85-0.71\right)$ with decreasing $\mathrm{MgO}$, attests to the importance of plagioclase fractionation during their petrogenesis. $\mathrm{Th} / \mathrm{Ta}$ and $\mathrm{La} / \mathrm{Ta}$ for the DIT intrusions (2.4-3.4 and 17-26 respectively) are similar to those for the E-W intrusions. Multi-element diagrams (Fig. 7) show that DIT intrusions exhibit troughs at Ti and P relative to adjacent elements, and a progressively larger negative $\mathrm{Sr}$ anomaly is developed with decreasing 
MgO. Plagioclase-phyric samples WI-5 and FAR338 exhibit a positive Sr spike in Fig. 7, which is presumably a result of accumulation of plagioclase feldspar, although neither sample exhibits a Eu anomaly. The distribution of trace elements in DIT intrusions bears a strong resemblance to those for Ferrar dolerites from the Transantarctic Mountains (Fig. 7). DIT intrusions have ${ }^{87} \mathrm{Sr}^{86} \mathrm{Sr}_{182}$ in the range $0.7055-0.7170$ but all samples with ${ }^{87} \mathrm{Sr} /{ }^{86} \mathrm{Sr}_{182}>0.7090$ contain $<2$ weight $\% \mathrm{MgO} . \quad \varepsilon \mathrm{Nd}_{182}$ falls in the range -2.8 to +0.6 , and there is no systematic variation between $\mathrm{MgO}, \varepsilon \mathrm{Nd}_{182}$ or ${ }^{87} \mathrm{Sr} /{ }^{86} \mathrm{Sr}_{182}$ (Figs 8 \& 9).

Mount Alice Type intrusions (MAT). MAT intrusions are restricted to the south-western area of West Falkland, around South Harbour, Dyke Island and Cape Orford (Fig.1) and are early Jurassic in age (188 $\pm 2 \mathrm{Ma}$ for sample MA3; Mussett \& Taylor 1994). MAT intrusions are generally $<1 \mathrm{~m}$ thick and are characterized by plagioclase \pm augite \pm olivine phenocrysts in a fine-grained groundmass. Since the area in which the MAT intrusions occur is within the region of the radial dyke swarm described Richards et al. (2013), azimuths cannot be used as one of their classification criteria, although in the region of Cape Orford, MAT dykes are generally oriented E-W (Mussett \& Taylor 1994; Thistlewood et al. 1997). A typical example (MFH15.2) contains sparse, scattered phenocrysts of olivine $\left(\mathrm{Fo}_{80}\right)$, calcic augite $\left(\mathrm{En}_{31} \mathrm{Fs}_{25} \mathrm{Wo}_{44} ;\right.$ Fig. 5) and labradorite $\left(\mathrm{An}_{60}\right) . \mathrm{MgO}$ varies from 6-12wt\%, and the MAT intrusions have the lowest $\mathrm{SiO}_{2}$ (46-50wt\%) for a given $\mathrm{MgO}$ content of any of the Falklands Islands samples (Fig. 4). $\mathrm{TiO}_{2}$ abundances (1.3-2.0wt\%) overlap with those for both the PST and E-W intrusions but $\mathrm{Ti} / \mathrm{Zr}$ is in the range 90-150 (Fig. 10) which is considerably higher than any other of the Falkland Islands intrusions. MAT intrusions have $[\mathrm{La} / \mathrm{Yb}]_{\mathrm{N}}$ in the range 1.8-3.1 (Fig. 6) and flat to slightly LREE-depleted REE profiles for elements $\mathrm{La}$ to $\mathrm{Sm}\left([\mathrm{La} / \mathrm{Sm}]_{\mathrm{N}}\right.$ 0.9-1.5). On multi-element diagrams (Fig. 7), MAT intrusions exhibit a positive Sr spike relative to N-ORB, but otherwise have smooth profiles from elements $\mathrm{Nd}$ to $\mathrm{Lu}$, with $\mathrm{Ti} / \mathrm{Zr}$ and $\mathrm{P} / \mathrm{Zr}$ (98-130 and 8.0-10.4 respectively) in the range for normal ORB (Ti/Zr c. 100, P/Zr c. 6.9; Sun \& McDonough 1987). Unlike all the other Falkland Islands intrusions, the MAT have $\mathrm{Th} / \mathrm{Ta}$ and $\mathrm{La} / \mathrm{Ta}(0.7-1.0$ and 
207 13-17 respectively) which are also within the range for normal ocean ridge basalts and 208 asthenosphere-derived basalts (Sun \& McDonough 1987). Sr- \& Nd-isotopic compositions fall 209 in the upper-left quadrant of Fig. 8, with $\varepsilon \mathrm{Nd}_{182}>5$ and ${ }^{87} \mathrm{Sr}^{86} \mathrm{Sr}_{182}<0.7040$. Pb-isotopic 210 compositions fall just above the NHRL with ${ }^{206} \mathrm{~Pb} /{ }^{204} \mathrm{~Pb}$ in the range 18.2-18.5 (Fig. 8).

\section{Petrogenesis of the Falkland Islands intrusions}

212 The diversity of major and trace element geochemistry and isotopic compositions of the 213 Falkland Islands intrusions requires an equally diverse range of petrogenetic histories. In 214 particular, the observed ranges of isotopic compositions described above are likely to require 215 variable interaction between isotopically depleted melts from mantle peridotite with melts 216 derived from continental lithosphere, which in some cases, must of considerable antiquity. 217 Consequently, before attempting to make regional comparisons between the Falkland Islands 218 intrusions and other Gondwana break-up related low $\mathrm{TiO}_{2}$ suites within the southern 219 hemisphere, an assessment of the petrogenetic history of each of the suites of Falkland Island intrusions will be made in turn below.

\section{PST intrusions}

PST and low $\mathrm{TiO}_{2}$ DIT intrusions exhibit variations in major element compositions that fall along the same fractionation trend as low $\mathrm{TiO}_{2}$ basaltic-andesites and andesites from the Theron Mountains (Fig. 11). However, PST and DIT intrusions cannot be related to one another by simple crystal fractionation because their $\mathrm{Sr}-, \mathrm{Nd}-$ and $\mathrm{Pb}$-isotopic compositions differ significantly from one another (Fig. 8). The high ${ }^{87} \mathrm{Sr}^{86}{ }^{86} \mathrm{Sr}_{182}(>0.710)$ and unradiogenic Ndisotopic compositions of the PST is a feature they share with Ferrar Province igneous rocks. Fleming et al. (1995) and Molzhan et al. (1999) demonstrated that elevated ${ }^{87} \mathrm{Sr}^{86} \mathrm{Sr}_{182}(0.7090$ 0.7112) of MFCT basalts was partly a function of Rb and Sr mobility during a Cretaceous (97$125 \mathrm{Ma})$ hydrothermal event. However, the observed range in $\varepsilon \mathrm{Nd}_{182}$ in the same samples $(-4.8$ to -5.6) is unlikely to be the result of alteration, and Fleming et al. (1995) concluded from 
analysis of phenocryst pahses, that prior to alteration, MFCT basalts must have had ${ }^{87} \mathrm{Sr} /{ }^{86} \mathrm{Sr}_{182} \geq 0.7090$. Alteration by the same regional hydrothermal thermal event cannot be used as an explanation for variability in the Sr-isotopic compositions of PST intrusions because the Falkland Islands would have already broken-away from the Antarctic continent by this time. In addition, the range of $\varepsilon \mathrm{Nd}_{182}$ from -6 to -12 over the limited range of ${ }^{87} \mathrm{Sr}^{86} \mathrm{Sr}_{182}=0.7110$ 0.7115, for the PST intrusions, requires potential contaminants that had a range of Nd-isotopic compositions and were therefore probably of differing ages.

Interaction with the continental lithosphere. For the PST intrusions, the variations shown in Fig. 9 indicate that $\mathrm{Sr}-$ and $\mathrm{Nd}$-isotopic variations were imposed on the magmas concomitant with fractional crystallization, by assimilation with fractional crystallization (AFC) or a similar process. The relationships shown in Fig. 9 require that $\mathrm{Sr}$ behaved incompatibly during fractional crystallization of the PST suite. The crystal cumulate formed during AFC cannot, therefore, have been plagioclase-rich. To generate the range of Sr-isotopic compositions seen in

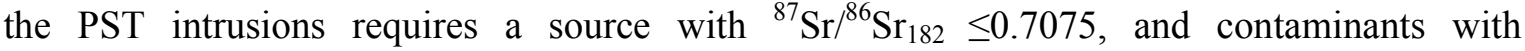
${ }^{87} \mathrm{Sr}^{86} \mathrm{Sr}_{182}>0.7130$ and a range of $\varepsilon \mathrm{Nd}_{182}$, which must be $\leq-6.0$ for all samples. Least-squares modelling of the extract and evolved liquid from a starting composition with $9.6 \mathrm{wt} \% \mathrm{MgO}$ (NGF16) to evolved composition with 6.78wt\% MgO (MHF5.1; Table 3) requires 21\% crystallization of an assemblage of orthopyroxene (74.7\%), plagioclase (18.9\%) and minor augite $(6.4 \%)$. With only $18.9 \%$ of the fractionating assemblage being plagioclase, $\mathrm{D}_{\mathrm{Sr}}$ would have been $<1$ which is consistent with the relationship between $1 / \mathrm{Sr}$ and ${ }^{87} \mathrm{Sr}^{86} \mathrm{Sr}_{182}$ in Fig. 9 . In addition, Demarchi et al. (2001) showed that orthopyroxene is on the liquidus of Ferrar tholeiites at 1.0-1.5 GPa, suggesting that magmatic differentiation of the PST intrusions occurred a depths $\geq 30 \mathrm{~km}$.

Sr- and Nd-isotopic compositions for PST intrusions fall in an intermediate position between the data for CT1 basalts of Dronning Maud Land and the Karoo (Fig. 12). Luttinen \& Furnes (2000) argued that the extreme $\mathrm{Nd}$-isotopic compositions $\left(\varepsilon \mathrm{Nd}_{182} \leq-17\right)$ of CT1 basalts were the 
result of interaction between a mantle-derived magma and Archean (3.0 Ga) Grunehogna cratonic lithosphere (Fig. 1). Riley et al. (2006) used AFC and energy-constrained recharge AFC to model the isotopic compositions of Karoo basaltic rocks using an ORB-like source and an assimilant with $\varepsilon \mathrm{Nd}_{182}=-4$ and ${ }^{87} \mathrm{Sr}^{86} \mathrm{Sr}_{182}=0.710$, and showed that the observed isotopic variability in the basalts could be explained partly by these processes. In Fig. 12 three AFC trajectories are plotted and the parameters used to generate the curves are given in Table 4. These are not designed to fully explain the isotopic diversity in Gondwana low $\mathrm{TiO}_{2}$ continental flood basalts, they have been generated in an attempt to constrain possible and impossible petrogenetic processes. The starting composition has been kept constant, and is based on that of largely uncontaminated low $\mathrm{TiO}_{2}$ basalts with $\varepsilon \mathrm{Nd}_{182}=2$ and ${ }^{87} \mathrm{Sr} /{ }^{86} \mathrm{Sr}_{182}=0.7035$. For all three modelled AFC trends, the ratio of the country rock assimilated to crystal cumulate formed, $R$, has be set at 0.40 , a value that is appropriate for crystallization in the middle- to upper-crust (Riley et al. 2006; Hole et al. 2015). $D_{\mathrm{Sr}}$ and $D_{\mathrm{Nd}}$ are set at 0.5 and 0.1 respectively, to simulate a cumulate with approximately $25 \%$ plagioclase, and $75 \%$ ferromagnesian minerals. This means that all three AFC trajectories approach the composition of the most contaminated magma for $\leq$ $20 \%$ AFC (Table 4). Increasing the value of $R$ to 0.5 for any of the models does not significantly change the shape of the trajectories, but decreases the amount of AFC that is needed to reach the target compositions to $\leq 12 \%$, and conversely, decreasing $\mathrm{R}$ to 0.3 requires $\leq 25 \%$ AFC. For the CT1 AFC model, the contaminant represents 3.0 Ga Grunehogna Craton (Fig. 1) felsic granulite, with $\varepsilon \mathrm{Nd}_{182}=-50$ and ${ }^{87} \mathrm{Sr} /{ }^{86} \mathrm{Sr}_{182}=0.712$ (felsic xenolith sample X4-AVL of Luttinen \& Furnes 2000). The PST-1, mixing line intersects the lowest $\varepsilon \mathrm{Nd}_{182}$ samples in the PST suite, and the contaminant represents a $2.2 \mathrm{Ga}$ Palaeoproterzoic felsic granulite with $\varepsilon \mathrm{Nd}_{182}=-20$ and ${ }^{87} \mathrm{Sr}^{86} \mathrm{Sr}_{182}=0.720$ (Luttinen \& Furnes 2000). The PST-2 mixing line, which also intersects the majority of data for Karoo basalts and lowest ${ }^{87} \mathrm{Sr}^{86} \mathrm{Sr}_{182}(\sim 0.7090)$ samples of Ferrar igneous rocks, representing mixing between a mantle-derived magma and 1.0-1.5 Ga felsic crust with $\varepsilon \mathrm{Nd}_{182}=-10$ and is the same contaminant as that suggested by Riley et al. (2006) for Karoo 
basalts. Plate reconstructions place the Falkland Islands mainly within the $1.0-1.5 \mathrm{Ga}$ Namaqualand-Natal-Maudheim-Mozambique belt (Thistlewood et al. 1997) and on the continuation of the Cape Fold Belt (Fig. 1). Mesoproterozoic crust is therefore a likely candidate for basement to the Falkland Islands, although there are no isotopic data for the Cape Meredith metamorphic complex. What is also clear is that cratonic basement like that involved in the petrogensis of the CT1 basalts affected neither the PST intrusions nor Karoo low $\mathrm{TiO}_{2}$ basaltic characteristics of the PST intrusions for $<20 \%$ AFC.

Pyroxenite versus peridotite sources. PST intrusions with $\mathrm{MgO}>8$ weight $\%$ have lower $\mathrm{CaO}$ abundances (c. 8.5 weight \%) than any other of the other Falkland Islands intrusions (Figs. 4 and 13). Such compositions are uncommon in continental flood basalts provinces. Orthopyroxene 
subduction history of the mantle source from which Ferrar and Karoo basaltic rocks were derived has been made by a number of workers (e.g. Brewer et al. 1992; Storey et al. 1992; Heinonen et al. 2014) and in particular, the characteristic trough at $\mathrm{Nb}$ and $\mathrm{Ta}$ relative to adjacent elements (Fig. 7) has been interpreted as an inherited subduction signature.

Herzberg \& Asimow (2008) note that primary magmas derived from the melting of pyroxenite will exhibit relative $\mathrm{CaO}$ depletion compared to melts from a peridotite source because of the dominance of residual clinopyroxene in the source region during partial melting of pyroxenite. Given the position that data for the PST occupy in Fig. 12, it seems clear that their major element compositions are not consistent with an origin by melting of mantle peridotite. It is well established that pyroxenite can be formed at the base of the lithosphere as a result of accumulation of mafic phases during basaltic magmatism (e.g. Downes et al. 2007). Such accumulative pyroxenite can yield magma by partial melting at some later stage, promoted by a new phase of mafic magmatism and by interaction with peridotite-derived melts (Lambart et al. 2013). The generation of silica-enriched pyroxenite melts is possible, which can yield Sioversaturated melts like those of the PST intrusions (Lambart et al. 2013). It is therefore suggested that the PST were derived from a pyroxenite-rich source that was emplaced at the base of the lithosphere during the prolonged subduction history of Gondwana. Metasomatism of the pyroxenite by slab-derived fluids and melt, imparted a subduction signature to the pyroxenite. When subjected to the high mantle potential temperatures associated with the mantle plume beneath Dronning Maud Land at c. $180 \mathrm{Ma}\left(\mathrm{T}_{\mathrm{P}}\right.$ up to $1600^{\circ} \mathrm{C}$; Heinonen et al. 2010), the pyroxenite underwent partial melting and produced the primary melt precursor to the PST intrusions. These melts then interacted with fusible, felsic continental crust to produce the geochemical composition of the more evolved PST compositions by AFC, or a related process. Extrapolation of the $\mathrm{MgO}-\varepsilon \mathrm{Nd}_{182}$ trend for the PST to higher $\mathrm{MgO}$ contents (Fig. 9a), suggests that a primitive composition with 15 weight $\% \mathrm{MgO}$ might have had $\varepsilon \mathrm{Nd}_{182} \sim 0$, and the 
335 correlation between $1 / \mathrm{Sr}$ and $\mathrm{Sr}$-isotopic compositions requires the source to have ${ }^{87} \mathrm{Sr} /{ }^{86} \mathrm{Sr}_{182} \leq$ 3360.7075.

\section{$337 \quad E-W$ intrusions}

338 Least-squares modelling of the extract and evolved liquid from a starting composition ECF12 to more evolved sample ECF44 (Table 3) requires crystal fractionation of 57\% olivine and 40\% 340 plagioclase feldspar with little contribution from augite (c. $2.6 \%$ ) which is a typical 341 crystallizing assemblage for tholeiitic melts at pressures $\leq 0.5 \mathrm{GPa}$ (e.g. Hole \& Morrison 1992; 342 Villiger et al. (2007), requiring E-W intrusions to have last equilibrated at $<\sim 15 \mathrm{~km}$ depth, within the crust. This is in contrast to the $>1.0 \mathrm{GPa}$ equilibration required by PST intrusions.

The isotopic compositions of E-W intrusions require derivation from a depleted mantle source (Figs 8), but they have higher $\mathrm{Th} / \mathrm{Ta}(2.2-2.8)$ and $\mathrm{La} / \mathrm{Ta}$ (16.4-26.1) than would be expected if they were derived from asthenospheric mantle $(\mathrm{Th} / \mathrm{Ta} \sim 1.0$ and $\mathrm{La} / \mathrm{Ta} \leq 18$; Sun $\&$ Mcdonough 1989) and they also exhibit a noticeable trough at $\mathrm{Nb}$ and $\mathrm{Ta}$ relative to adjacent elements in Fig. 7, a feature that is most often attributed to interaction with continental lithosphere. However, the extent of this interaction must either have been limited, or the source from which the E-W intrusions were derived had a $\mathrm{Th} / \mathrm{Ta}>2.0$ and $\mathrm{La} / \mathrm{Ta}>26$. The low pressure equilibration of E-W intrusions, coupled with their depleted isotopic compositions may suggest thet they were emplaced during a period of crustal attenuation and were thus able to escape interaction with continental lithosphere.

\section{DIT and Lively Island intrusions}

In contrast to the PST intrusions, the sub-horizontal arrays delineated by DIT intrusions in Fig. 9a, suggests that AFC or a similar process was not important during their petrogenesis. However, a negative correlation between $\mathrm{Th} / \mathrm{Ta}$ and $\varepsilon \mathrm{Nd}_{182}$ for the DIT intrusions (Fig. 9b) may require minor modification by a crustal component with $\mathrm{Th} / \mathrm{Ta} \geq 3.0$. A characteristic feature of the DIT samples is that they have $\varepsilon \mathrm{Nd}_{182}$ in range -2.8 to +0.6 , but with only a single analysed sample (NHF17) having $\varepsilon \mathrm{Nd}_{182}<-1$. In addition, the Lively Island dyke, which falls close to the 
fractionation trend for the MFCT basaltic rocks of the Transantarctic Mountains (Fig. 11), has Sr- and Nd-isotopic compositions $\left({ }^{87} \mathrm{Sr}^{86}{ }^{86} r_{182}\right.$ c. $0.7052, \varepsilon \mathrm{Nd}_{182}=-0.5$ to -1.4$)$ that do not require the significant isotopic enrichment seen in the Ferrar dolerites $\left(\varepsilon \mathrm{Nd}_{182}\right.$ in the range -3.3 to -5.3; Fleming et al. 1995; Hergt et al. 1989). The source of the low $\mathrm{TiO}_{2} \mathrm{DIT}$ magmas could, therefore, have had $\varepsilon \mathrm{Nd}_{182}>0,{ }^{87} \mathrm{Sr} /{ }^{86} \mathrm{Sr}_{182}<0.7050, \mathrm{Th} / \mathrm{Ta}<2.5$ and $\mathrm{La} / \mathrm{Ta}<20$.

\section{MAT intrusions}

The positive $\varepsilon \mathrm{Nd}_{182}(2.7-3.6)$ and low $\mathrm{Th} / \mathrm{Ta}, \mathrm{La} / \mathrm{Ta}$ and $[\mathrm{La} / \mathrm{Yb}]_{\mathrm{N}}(0.8-1.0 ; 12.8-17.3$ and $1.9-$ 3.7 respectively) of MAT intrusions suggests that they were derived from an asthenospheric source, and escaped significant interaction with lithosphere. The most satisfactory explanation for the geochemical compositions of these rocks is that they were generated by decompression melting of the asthenosphere during the rifting stage of Gondwana break-up. In this respect they have similar geochemical compositions to the ORB-like Rooi Rand basaltic dykes of the southern Lebombo (Cox \& Bristow 1984, which post-date the main magmatic phases in the region by about $5 \mathrm{Myr}$ (Jourdan et al. 2007).

\section{Cretaceous intrusions}

Until more data are forthcoming, the origin and affinity of the Cretaceous Teal Creek intrusion reported by Stone et al. (2009) remains somewhat obscure. Major element data for the intrusion plot close to the Theron Mountains low $\mathrm{TiO}_{2}$ trend in Fig. 6, but the intrusion has higher $\mathrm{Fe}_{2} \mathrm{O}_{3}$ (c. $15.9 \mathrm{wt} \%$ ) at $5.7 \mathrm{wt} \% \mathrm{MgO}$ than any of the data for the intrusions presented here. What is clear, is that there is an extensive suite of low $\mathrm{TiO}_{2}$ basalts within the Etendeka Province (e.g. Gibson et al. 2005; Thompson et al. 2001) from which it could be related. However, none of the groups of intrusions described here carries a similar signature to that presented by Stone et al. (2009) for the Teal Creak dyke.

\section{Provinciality and chemical affinities of Falkland Islands intrusions}


A number of authors have noted that there are spatially constrained variations in major and trace element compositions within the Jurassic Gondwana break-up related flood basalts provinces of the Southern Hemisphere (e.g. Brewer et al. 1992; Luttinen \& Furnes 2000; Riley

et al. 2006). Figs 11 and 14 illustrate the variability in abundances of $\mathrm{MgO}, \mathrm{TiO}_{2}, \mathrm{SiO}_{2}$ and

$\mathrm{Ti} / \mathrm{Zr}$ for Falkland Island intrusions, along with igneous rocks which are defined as being either 
411 Nd-isotopic compositions $\left(\varepsilon \mathrm{Nd}_{182}=2-6\right){ }^{87} \mathrm{Sr} /{ }^{86} \mathrm{Sr}_{182}$ in the restricted range $0.7040-0.7060$ and

$412{ }^{206} \mathrm{~Pb} /{ }^{204} \mathrm{~Pb}$ in the range 17.97-18.49 and plot close to the NHRL in Fig. 8. These isotopic 413 characteristics, coupled with $\mathrm{Ti} / \mathrm{Zr}=70-90$ and $\mathrm{SiO}_{2}=47.0-52.8 \mathrm{wt} \%$, clearly separates 414 Kirwanveggan, Schirmaker Oasis and Falkand Islands E-W intrusions from PST intrusions. E415 W intrusions also fall within the compositional field for basalts from the Central Karoo of South 416 Africa in Fig. 14, and intrusions with compositions similar to those of Falkland Islands E-W 417 intrusions are prevalent in the Golden Valley Sill Complex (Neumann et al. 2011).

\section{DIT and Lively Island intrusions}

In Fig. 14b, DIT intrusions exhibit almost complete overlap with the MFCT Ferrar dolerites of the Transantarctic Mountains. However, consideration of Fig. 11, shows that DIT intrusions are not of the same low $\mathrm{TiO}_{2}(<0.5-1.2 \mathrm{wt} \%)$ lineage of the MFCT. However, DIT intrusions do have compositions that overlap with those for low $\mathrm{TiO}_{2}$ Theron Mountains basalts and samples from KwaZulul-Natal that Riley et al. (2006) and Brewer et al. (1992) argued were transitional between Ferrar and Karoo magma types. We concur with this hypothesis, and given the position that the Falkland Islands occupied in southern Gondwana at the time of Karoo and Ferrar magmatism, this seems entirely reasonable.

The Lively Island intrusion is the only member of the intrusive suite of rocks of the Falkland Islands that falls within the compositional range for MFCT samples from the Transantarctic Mountains in Figs 11 and 14. However, the Lively Island intrusion has considerably lower $\mathrm{La} / \mathrm{Ta}$ and $\mathrm{Th} / \mathrm{Ta}$ (20.5 and 3.2 respectively) than the majority of the MFCT dolerites ( $\mathrm{La} / \mathrm{Ta} 19-$ 47; $\mathrm{Th} / \mathrm{Ta}$ 4.3-23.3), and the Lively Island dyke also has considerably more radiogenic $\mathrm{Nd}$ $\left(\varepsilon \mathrm{Nd}_{182}=-0.5\right.$ to -1.4$)$ than MCFT dolerites $\left(\varepsilon \mathrm{Nd}_{182}=-4.7\right.$ to -5.7$)$. It is important to note, that the Lively Island intrusion is a single body of igneous rock around 30m thick, and consequently 434 is not a volumetrically significant part of the Falkland Islands dyke swarm.

\section{MAT intrusions}


$\mathrm{Ti} / \mathrm{Zr}>90$ coupled with $\mathrm{SiO}_{2}$ of $45.7-51.0 \mathrm{wt} \%$ are characteristics that MAT intrusions share

with CT2 and CT3 basalts from Dronning Maud Land and samples from the Rooi Rand dyke

swarm of the southern Lebombo area of southern Africa (Cox \& Bristow 1984).. The

unradiogenic Sr-isotopic compositions $\left({ }^{87} \mathrm{Sr} /{ }^{86} \mathrm{Sr}_{182}\right.$ c. 0.7040$)$ and radiogenic Nd-isotopic

compositions $\left(\varepsilon \mathrm{Nd}_{182}=2.5-4.0\right)$ of E-W intrusions also characterize Rooi Rand and CT2 and

CT3 basalts, although the Dronning Maud Land samples have a rather more extended range of isotopic compositions, which Luttinen \& Furnes (2000) attribute to conservative amounts of interaction with upper-crustal felsic contaminants.

\section{Mantle potential temperature, rifting and magmatism}

Fig. 15a summarizes the available data for olivine equilibration temperatures $\left(\mathrm{T}_{\mathrm{OL}}\right)$ for $\mathrm{MAT}$ and E-W basalts and picrites from Dronning Maud. MAT and E-W basalts yield olivine equilibration temperatures of $1245^{\circ} \mathrm{C}$ and $1330^{\circ} \mathrm{C}$ respectively, using the method of Putirka et al. (2007), whilst olivine in picrites from Dronning Maud Land yield $\mathrm{T}_{\mathrm{OL}}$ up to $1450^{\circ} \mathrm{C}$.

Converting equilibration temperatures to $T_{P}$ is problematical if the pressure and extent of melting cannot be independently determined (Herzburg \& Asomow 2008; Herzburg \& Gazel 2009; Hole 2015), which they cannot for the MAT and E-W samples. However, since olivine equilibration temperature increases with increasing pressure of crystallization, synthetic olivine liquidi can be calculated for any given temperature and pressure (Herzberg \& Gazel 2009). Fig. $15 \mathrm{~b}$ shows the inferred temperature-pressure conditions at which fractional melting terminated for calculated primary magmas from Dronning Maud Land, the Karoo Province of southern Africa, Ferrar dolerites of Antarctica. (Hole 2015). In Fig. 15c, data for basalts from the

457 Cretaceous Etendeka Province of SW Africa (Kieding et al. 2011) are given, for which estimates of $\mathrm{T}_{\mathrm{OL}}$, estimates of $\mathrm{T}_{\mathrm{P}}$ from melt inclusions in ultra-magnesian olivine, and estimates of $\mathrm{T}_{\mathrm{P}}$ from the PRIMEL2 model of Herzberg \& Asimow (2008) have all been calculated on the same samples. Using the Herzberg \& Asimow (2008) model yields $\mathrm{T}_{\mathrm{P}}=1500-1550^{\circ} \mathrm{C}$ and final pressures of melting $(\mathrm{Pf})$ between 1.5 and 4.0 GPa (Fig. 13c). $\mathrm{T}_{\mathrm{P}}$ from melt inclusions is 1300- 
$1520^{\circ} \mathrm{C}$, whilst $\mathrm{T}_{\mathrm{OL}}$ is in the range $1250-1400^{\circ} \mathrm{C}$ and there is an empirical relationship between

$463 \mathrm{~T}_{\mathrm{OL}}$ and melt inclusion $\mathrm{T}_{\mathrm{P}}$ which approximates to $\mathrm{T}_{\mathrm{P}}=1.443 \times \mathrm{T}_{\mathrm{ol}}-501$ for the Etendeka plume system (Fig. 15). Therefore is seems that within a single plume system, basalts may be generated over ranges of $\mathrm{T}_{\mathrm{P}}$ that are larger than the $\pm 50^{\circ} \mathrm{C}$ error inherent in the calculation methods (Herzberg \& Asimow 2009; Hole 2015). Direct application of this empirical observation to the Dronning Maud Land picrites suggest maximum $\mathrm{T}_{\mathrm{P}} \sim 1550^{\circ} \mathrm{C}$, a temperature that is considered to be associated with 'hot' mantle plumes such as Iceland at $60 \mathrm{Ma}$ (Fig. 15; Herzberg \& Gazel 2009). For Falkland Islands E-W basalts, $\mathrm{T}_{\mathrm{OL}} \sim 1330^{\circ} \mathrm{C}$, which implies $\mathrm{T}_{\mathrm{P}} \sim 1400^{\circ} \mathrm{C}$ and for olivine-phyric MAT basalts, $\mathrm{T}_{\mathrm{OL}} \sim 1250^{\circ} \mathrm{C}$ implying $\mathrm{T}_{\mathrm{P}} \sim 1300^{\circ} \mathrm{C}$. These $\mathrm{T}_{\mathrm{P}}$ estimates for the Falkland Islands E-W and MAT basalts may therefore be reconciled with a model involving melting of mantle with near-ambient temperature $\left(T_{P} \geq 1350^{\circ} \mathrm{C}\right)$, but would require intersection of the dry peridotite solidus at $\sim 2.1 \mathrm{GPa}(\sim 70 \mathrm{~km})$ and all melting to take place in the spinel stability field of the mantle; the most mafic MAT and E-W intrusions have $[\mathrm{La} / \mathrm{Yb}]_{\mathrm{N}}<2.0$ which does not preclude such an origin. Additionally, near-ambient $\mathrm{T}_{\mathrm{P}}$ melting would require the continental lithosphere to be thinned substantially and perhaps to $<50 \mathrm{~km}$, to allow decompression melting to take place. The depleted isotopic compositions of the E-W and MAT intrusions, along with the $<0.5 \mathrm{GPa}$ equilibration of the E-W magmas, provides additional evidence to suggest that these intrusions were emplaced during a period of crustal stretching, possible coeval with the initiation of Gondwana. Nevertheless, whilst there is no primary evidence to suggest $\mathrm{T}_{\mathrm{P}}$ was $>1450^{\circ} \mathrm{C}$ beneath the Falkland Islands at $180 \mathrm{Ma}$, it is possible that high-MgO large melt fractions requiring substantially higher $\mathrm{T}_{\mathrm{P}}$ exist in the region, but have not been sampled, remains a possibility. close to the focus of magmatism during continental break-up. We concur with Brewer et al.

The diversity of magma types found in the Falkland Islands, and the position in Gondwana which the islands occupied during magmatism (Fig. 1) is entirely consistent with the their being (1992) and Riley et al. (2006) that there is considerable overlap in the geographical distribution 
of the Ferrar and Karoo LIPs, which is most obvious in the Theron Mountains and Falkland Islands. It is also clear, that despite the wealth of geochemical data available for the Transantarctic Mountains and Tasmania, there is no evidence to suggest that volcanic rocks with affinities to the Karoo LIP occur in those areas. With the exception of the ORB-like basalts of the Rooi Rand dyke swarm (Marsh et al. 1997; Mitchell et al. 1999) which are likely to represent syn-break-up magmas, basaltic rocks with Karoo-type geochemical compositions only extend as far south as the overlap zone in the Theron Mountains.

\section{Conclusions}

The Jurassic (c. $182 \mathrm{Ma}$ ) intrusions of the Falkland Islands exhibit a broad range of geochemical compositions and at least four main petrogenetic lineages are recognized. PST intrusions were derived by melting of an isotopically-enriched pyroxenite-rich source, followed by orthopyroxene-dominated crystal fractionation at $\geq 1 \mathrm{GPa}$. Pyroxenite-derived PST magmas subsequently interacted with 'old' $(\geq 2.2 \mathrm{Ga}$ ) fusible continental lithospheric components by AFC or a related process. The geochemical compositions of DIT intrusions bear striking similarities to igneous rocks of Kwazulu-Natal and the Theron Mountains, which are considered to be transitional in composition between those of the Ferrar and Karoo magma types. A significant number of mafic (Mg\# 50-62) E-W and MAT intrusions possess radiogenic $\mathrm{Nd}-$ and unradiogenic Sr-isotopic compositions $\left({ }^{87} \mathrm{Sr}^{86} \mathrm{Sr}_{182}<0.7050\right.$ and $\left.\varepsilon \mathrm{Nd}_{182}>2.5\right)$, also have $\mathrm{Th} / \mathrm{Ta}$ and $\mathrm{La} / \mathrm{Ta}(<3.0$ and $<25$ respectively) that require little input from the continental lithosphere. In addition, E-W intrusions carry mineralogical and chemical fingerprints of equilibration at < $0.5 \mathrm{GPa}$. E-W and MAT basalts were probably emplaced during rifting and continental break-up and are likened to the Rooi Rand dykes of the Southern Lebombo of Africa. However, there is currently no evidence to suggest that the Falkland Islands intrusions were derived by melting above a significant mantle thermal anomaly. Early Jurassic plate reconstructions place the

512 Falkland Islands close to the Weddell Triple Junction, perhaps explaining the diversity of 513 igneous rock compositions found in a relatively limited geographical region. 


\section{Acknowledgements.}

515 An earlier version of the manuscript was improved by thoughtful comments from two 516 anonymous reviewers. Dr D. Aldis, Falkland Islands Geological Survey, is thanked for 517 providing some samples from Fox Bay West for this study. 


\section{References Cited.}

Antonini, P., Piccirillo, E.M., Petrini, R., Civetta, M., D’Antonio, M. \& Orsi, G. 1999. Enriched mantle Dupal signature in the genesis of the Jurassic Ferrar tholeiites from the Prince Albert Mountains, (Victoria Land, Antarctica). Contributions to Mineralogy and Petrology, 136, 119.

Baker, M.B., Grove, T.L. and Price, R.C. 1994. Primitive basalts and andesites from the Mt. Shasta region, N. California: products of varying melt fraction and water content. Contributions to Mineralogy and Petrology, 118, 111-129.

Brewer, T. S., Hergt, J. M., Hawkesworth, C. J., Rex D. C. \& Storey B. C. 1992. Coats Land dolerites and the generation of Antarctic continental flood basalts. In: Storey, B. C., Alabaster, T. \& Pankhurst, R. J. (eds) Magmatism and the causes of Continental Break-Up Geological Society, London, Special Publications, 64, 185-208.

Burgess, S.D., Bowring, S.A., Fleming, T.H. \& Elliot, D.H. 2015. High-precision geochronology links the Ferrar large igneous province with early-Jurassic ocean anoxia and biotic crisis. Earth and Planetary Science Letters, 415, 90-99.

Coltice, N., Bertrand, H., Rey, P.M., Jourdan, F., Phillips, B.R. \& Ricard, Y. 2009. Global warming of the mantle beneath continents back to the Archaean. Gondwana Research, 15, 254-266.

Cox, K.G. \& Bristow, J.W. 1984. The Sabine River Basalt Formation of the Lebombo Monocline and south-east Zimbabwe. In: Petrogenesis of the volcanic rocks of the Karoo province, A.J. Erlank (ed). Special Publication of the Geological Society of South Africa, 13, 124-147.

Demarchi, G., Antonini, P., Piccirillo, E.M., Orsi, G., Civetta, L. \& D’Antonini, M. 2001. Significance of orthopyroxene and major element constraints on the petrogenesis of Ferrar tholeiites from southern Prince Albert Mountains, Victoria Land, Antarctica. Contributions to Mineralogy and Petrology, 142, 127-146.

Downes, H., Upton, B.G.J., Connolly, J., Beard, A.D. \& Bodinier, J-L 2007. Evidence for late Palaeozoic crustal underplating beneath SW Scotland Petrology and geochemistry of a cumulate xenolith suite from Bute. Journal of the Geological Society, London, 164, 12171231.

Elliot, D.H. 2013. The geological and tectonic evolution of the Transantarctic Mountains: a review. In: Hambrey, M.J., Barker, P.F., Barrett, P.J., Bowman, V., Davies, B., Smellie, J.L. \& Tranter, M (eds). Antarctic Palaeoenvironments and Earth-surface process. Geological Society London, Special Publications, 381, 7-35. 
Elliot, D. H. \& Fleming, T. H. 2000. Weddell Triple Junction: The principal focus of Ferrar and Karoo magmatism during the initial break-up of Gondwana. Geology, 28, 539-542.

Elliot, D. H. \& Fleming, T. H. 2004. Occurrence and Dispersal of Magmas in the Jurassic Ferrar Large Igneous Province, Antarctica. Gondwana Research, B, 223-237.

Elliot, D.H., Fleming, T.H., Haban, M.A. \& Siders, M.A. 1995. Petrology and mineralogy of the Kirkpatrick Basalt and Ferrar Dolerite, Mesa Region, Northern Vitoria Land, Antarctica. In: Elliot, D.H. \& Blaisdell, L.L. (eds) Contribution to Antarctic Research IV. Antarctic Research Series, 67. American Geophysical Union, Washington DC, 103-141.

Elliot, D. H., Fleming, T. H., Kyle, P. R. \& Foland, K. A. 1999. Long-distance transport of magmas in the Jurassic Ferrar large igneous province, Antarctica. Earth and Planetary Science Letters, 167, 89-104.

Fleming, T.H., Foland, K.A. \& Elliot, D.H. 1995. Isotopic and chemical constraints on the crustal evolution and source signature of Ferrar magmas, north Victoria Land, Antarctica. Contributions to Mineralogy and Petrology, 121, 217-236.

Galerne,C.Y., Nuemann, E-R. \& Planke, S. 2008. Emplacement mechanisms of sill complexes: Information from the geochemical architecture of the Golden Valley Sill Complex, South Africa. Journal of Volcanology and Geothermal Research, 177, 425-440.

Gibson, S.A., Thompson, R.N., Day, J.A., Humphris, S.E. \& Dickin A.P. 2005. Melt-generation associated with the Tristan mantle plume: constraints on the origin of EM-1. Earth and Planetary Science Letters, 237, 744-767.

Greenway, M. E., 1972. The geology of the Falkland Islands. British Antarctic Survey Scientific Reports, 76, $42 \mathrm{pp}$.

Harris, C., Marsh, J.S., Duncan, A.R. \& Erlank, A.J. 1990. The Petrogenesis of the Kirwan Basalts of Dronning Maud Land, Antarctica. Journal of Petrology, 31, 341-369.

Heinonen, J.S. \& Luttinen, A.V. 2008. Jurassic dikes of Vestfjella, western Dronning Maud Land, Antarctica: Geochemical tracing of ferropicrite sources. Lithos, 105, 347-364.

Heinonen, J.S., Carlson, R.W. \& Luttinen, A.V. 2010. Isotopic (Sr, Nd, Pb, and Os) composition of highly magnesian dikes of Vestfjella, western Dronning Maud Land, Antarctica: A key to the origins of the Jurassic Karoo large igneous province? Chemical Geology, 277, 227-244.

Heinonen, J.S., Luttinen, A.V., Riley, T.R. \& Nichallik, R.M. 2013. Mixed pyroxeniteperidotite sources for mafic and ultramafic dikes from the Antarctic segment of the Karoo continental flood basalt province. Lithos, 177, 266-380. 
Heinonen, J.S., Carlson, R.W., Riley, T.R., Luttinen, A.V. \& Horan, M.F. 2014. Subductionmodified oceanic crust mixed with a depleted mantle reservoir in the sources of the Karoo continental flood basalt province. Earth and Planetary Science Letters, 394, 229-241.

Hergt J. M., Chappell B. W., Mcculloch M. T., McDougall I. \& Chivas A. R. 1989. The geochemistry of Jurassic dolerites from Portal Peak, Antarctica. Contributions to Mineralogy and Petrology, 102, 298-305.

Herzberg, C. \& Asimow, P.D. 2008. Petrology of some oceanic island basalts: PRIMELT2.XLS software for primary magma calculation. Geochemistry, Geophysics, Geosystems, 9.

Herzberg, C. \& Gazel, E. 2009. Petrological evidence for secular cooling in mantle plumes. Nature, 458, 619-623.

Hole, M.J. 2015. The generation of continental flood basalts by decompression melting of internally heated mantle. Geology, 43.311-314.

Hole M.J. \& Morrison, M.A. 1992. The differentiated boss Cnoc Rhaonastil, Islay; a natural experiment in the low pressure differentiation of an alkali olivine-basalt magma. Scottish Journal of Geology, 28, 55-69.

Hole, M.J., Millett, J.M., Rogers, N.W. \& Jolley, D.W. 2015. Rifting and mafic magmatism in the Hebridean basins. Journal of the Geological Society, London, 172, 218-236.

Jourdan F., Bertrand H., Schärer U., Blichert-Toft J., Feraud G. \& Kampunzu A.B. 2007b. Major and trace element and $\mathrm{Sr}, \mathrm{Nd}, \mathrm{Hf}$, and $\mathrm{Pb}$ isotope compositions of the Karoo large igneous province, Botswana-Zimbabwe: lithosphere vs mantle plume contribution. Journal of Petrology, 48, 1043-1077

Keiding, J.K., Trumbull, R.B., Veksler, I.V. \& Jerram, D.A. 2011. On the significance of ultramagnesian olivines in basaltic rocks. Geology, 39, 1095-1098.

Lambart, S., Lapporte, D. \& Schiano, P. 2013. Markers of the pyroxenite contribution in the major-element compositions of oceanic basalts: Review of the experimental constraints. Lithos, 160-161, 14-36.

Luttinen, A.V. \& Furnes, H., 2000. Flood basalts of the Vestfjella: Jurassic magmatism across an Arcehan-Proterozoic lithospheric boundary in Dronning Maud Land, Antarctica. Journal of Petrology, 41, 1271-1305.

Luttinen, A.V., Ramo, O.T. \& Huhma, H. 1998. Neodymium and strontium isotope and trace element composition of a Mesozoic CFB suite from Dronning Maud Land, Antarctica: implications for lithosphere and asthenosphere contributions to Karroo magmatism. Geochimica et Cosmochimica Acta, 15, 2701-2714. 
Macdonald, D.I.M., Gomez-Perez, I., Franzese, J., Spalleti, L., Lawver, L., Gahagan, L., Dalziel, I.W.D., Thomas, C.J., Trewin, N.H., Hole, M.J. \& Paton, D. 2003. Mesozoic breakup of SW Gondwana: implications for regional hydrocarbon potential of the southern South Atlantic. Marine \& Petroleum Geology, 20, 287-308

Marsh, J.S., Hooper, P.R., Rehacek, J., Duncan, R.A. \& Duncan, A.R. 1997. Stratigraphy and age of Karroo basalts of Lesotho and implications for correlations within the Karroo Igneous Province. In: Mahoney, J.J. \& Coffin, M.F. (eds) Large Igneous Provinces, A G U Geophysical Monographs, 100, 247-272.

McClintock, M., Marsh, J. \& White, J.D.L. 2008. Compositionally diverse magmas erupted close together in space and time within a Karoo flood basalt crater complex. Bulletin of Volcanology, 70, 923-946.

Mitchell, C., Ellam, R.M. \& Cox, K.G. 1999. Mesozoic dolerite dykes of the Falkland Islands: petrology, petrogenesis and implications for geochemical provinciality in Gondwanaland low-Ti basaltic rocks. Journal of the Geological Society, London, 156, 901-916.

Molzahn, M., Reisberg, L. \& Wörner, G. 1996. Os, Sr, Nd, Pb, O isotope and trace element data from the Ferrar flood basalts, Antarctica: evidence for an enriched subcontinental lithospheric source. Earth and Planetary Science Letters, 144, 529-546.

Muirhead, J.D., Airoldi, G., White, J.L. and Rowland, J.V. 2014. Cracking the lid: Sill-fed dikes are the likely feeders of flood basalt eruptions. Earth and Planetary Science Letters, 406, 187-197.

Mussett, A.E. \& Taylor, G.K. 1994. ${ }^{40} \mathrm{Ar}-{ }^{39} \mathrm{Ar}$ ages for dykes from the Falkland Islands with implications for the break-up of southern Gondwanaland. Journal of the Geological Society, London, 151, 79-81.

Nuemann, E-R., Svensen, H., Galerne, G.Y. \& Planke, S. 2011. Multistage Evolution of Dolerites in the Karoo Large Igneous Province, Central South Africa. Journal of Petrology, 52, 959-984.

Putirka, K.D., Perfit, M., Ryerson, F.J. \& Jackson, M.G. 2007. Ambient and excess mantle temperatures, olivine thermometry, and active vs. passive upwelling. Chemical Geology, 241, 177-206.

Richards, P.C., Stone, P., Kimbell, G.S., Mcintosh, W.C. \& Phillips, E.R. 2013. Mesozoic magmatism in the Falkland Islands (South Atlantic) and their offshore sedimentary basins. Journal of Petroleum Geology, 36, 61-74. 
Riley, T.R., Curtis, M.L., Leat, P.T., Watkeys, M.K., Duncan, R.A., Millar, I.L. \& Owens, W.H. 2006. Overlap of Karoo and Ferrar Magma Types in KwaZulu-Natal, South Africa. Journal of Petrology, 47, 541-566.

Sato, M., Shuto, K., Nohara-Imanaka, R., Takazawa, E., Osanai, Y. \& Nakano, N. 2014. Repeatedmagmatism at $34 \mathrm{Ma}$ and 23-20 Ma producing highmagnesian adakitic andesites and transitional basalts on southern Okushiri Island, NE Japan arc. Lithos, 205, 60-83.

Sushchevskaya, N.M., Korago, E.A., Belyatsky, B.V. \& Sirotkin, A.N. 2009. Evolution of the Karoo-Maud mantle plume in Antarctica and its influence on the magmatism of the early stages of Indian ocean opening. Geochemistry International, 47, 1-17.

Stone, P., Kimbell, G.S. \& Richards, P.C. 2009. Rotation of the Falklands microplate reassessed after recognition of discrete Jurassic and Cretaceous dyke swarms. Petroleum Geoscience, 15, 279-287.

Stone, P., Richards, P.C., Kimbell, G.S., Esser, R.P.,\& Reeves, D. 2008 Cretaceous dykes discovered in the Falkland Islands: implications for regional tectonics in the South Atlantic. Journal of the Geological Society, London, 165, 1-4

Storey, B.C., Alabaster, T., Hole, M.J., Pankhurst, R.J. \& Wever, H. 1992. Role of subductionplate boundary forces during the initial stages of Gondwana break-up: Evidence from the proto-Pacific margin of Antarctica. In: Storey, B. C., Alabaster, T. \& Pankhurst, R. J. (eds) Magmatism and the causes of Continental Break-Up Geological Society, London, Special Publications, 64, 149-163.

Sweeney R. J., Duncan A. R., Erlank A. J. 1994. Geochemistry and Petrogenesis of Central Lebombo basalts of the Karoo igneous province. Journal of Petrology, 35 95-125.

Sun, S-S. \& Mcdonough, W. F. 1989. Chemical and isotopic systematics of oceanic basalts: implications for mantle composition and processes. In: Saunders, A.D. \& Norry, M.J., (eds). Magmatism in the ocean basins. Geological Society, London, Special Publications, 42, 313-345.

Sushchevskaya, N. M., Belyatskii, B. V., Leichenov, G. L. \& Laiba A. A. 2009. Evolution of the Karoo-Maud plume in Antarctica and its influence on the magmatism of the early stages of Indian Ocean opening. Geochemistry International, 47, 1-17

Svensen, H., Corfu, F., Polteau, S., Hammer, O \& Planke, S. 2012. Rapid magma emplacement in the Karoo Large Igneous Province. Earth and Planetary Science Letters, 325-326, 1-9.

Thistlewood, L., Leat, P. T., Millar, I.L., Storey, B.C. \& Vaughan, A. P. M. 1997. Basement Geology and Palaeozic-Mesozoic mafic dykes from the Cape Meredith Complex, Falkland 
Islands: a record of repeated intracontinental extension. Geological Magazine, 134, 355367.

685 Thompson, R.N., Gibson, S.A., Dickin, A.P. \& Smith, P.M. 2001. Early Cretaceous basalt and 686 picrate dykes of the Southern Etendeka region, NW Namibia: windows into the role of the 687 Tristan plume in Parana-Etendeka magmatism. Journal of Petrology, 42, 2049-2081.

688 Trewin, N.H., Macdonald, D.I.M., \& Thomas, C.G.C. 2002. Stratigraphy and sedimentology of 689 the Permian of the Falkland Islands: lithostratigraphic and palaeoenvironmental links with 690 South Africa. Journal of the Geological Society, London, 159, 5-19.

691 Villiger, S., Ulmer, P. \& Muntener, O. 2007. Equilibrium and fractional crystallization 692 experiments at $0.7 \mathrm{GPa}$; the effect of pressure on phase relations and liquid compositions of 693 tholeiitic magmas. Journal of Petrology, 48, 159-184.

694 Wilhelm, S. \& Wörner, G. 1996. Crystal size distribution in Jurassic Ferrar flows and sills 695 (Victoria Land, Antarctica): evidence for processes of cooling, nucleation and 696 crystallization. Contributions to Mineralogy and Petrology, 125, 1-15.

697 Williamson, I.T. \& Bell, B.R. 2012. The Staffa Lava Formation: graben-related volcanism, 698 associated sedimentation and landscape character during the early development of the 699 Palaeogene Mull Lava Field, NW Scotland. Scottish Journal of Geology, 48, 1-46.

700 
702 Figure 1. a) Reconstruction of Southern Gondwana showing the position of the Falkland Islands relative to south-eastern Africa prior to continental break-up. The three arrows represent the main dyke trends on the Falkland Islands rotated back to their pre-180 Ma orientation. After Trewin et al. (2002). b) Southern Gondwana, in the Middle Jurassic, showing the distribution of Jurassic break-up related magmas in southern Africa and Antarctica. MEB, Maurice Ewing Bank; EWM, Ellsworth-Whitmore Mountains; AP, Antarctic Peninsula; SA, South Africa; SAM, South America; ANT, Antarctica. Position of the Weddell, Limpopo and Lower Zambesi triple junctions are from Elliot \& Fleming (2000). Ar-Ar ages, this study and Stone et al. (2009). After Macdonald et al. (2003). Key to shading for Fig. 1b is the same as that for Fig. 1a.

Figure 2. Map of the Falkland Islands showing the distribution of magnetic anomalies and main trends of dyke swarms. Solid or pecked lines do not necessarily represent continuous exposure of dykes. Inset; azimuths of Dykes in the South Harbour area of West Falkland. The rectangle at South Harbour is the area covered by the map in the supplementary material, which gives the sample locations and geochenmical type to which the dykes belong in that area. After Stone et al. (2009) and Richards et al. (2013). Ar-Ar ages (this study, Stone et al. 2008; 2009) and sample locations which are mentioned in the text, are indicated, along with the geochemical group to which the intrusions belong, given by the following abbreviations; PST, Port Sussex Type; MAT, Mount Alice Type, E-W, East-West Type of Mitchell et al. (1999); DIT, Dyke Island Type. Identifying characteristics of each type of intrusion are discussed in detail in the text.

Figure 3. Ar-Ar step-heating spectrum for plagioclase in sample WI-5. Full data are given in the supplementary materials.

Figure 4. Major (wt\%) and trace element (in $\mathrm{ppm}$ ) variations versus $\mathrm{MgOwt} \%$ in Falkland Islands dykes. Filled dots, Port Sussex Creek type (PST) NE-SW two-pyroxene dolerites; open triangles, E-W olivine dolerite dykes; open squares, Lively Island dyke; filled squares, Mount Alice-type (MAT) dykes; open dots, low $\mathrm{TiO}_{2}$ DIT intrusions; filled diamonds, high $\mathrm{TiO}_{2} \mathrm{DIT}$ intrusions; open diamonds, evolved sheets from the South Harbour-Dyke Island transect (Dyke Island Type; DIT); crosses, Pony's Pass N-S Cretaceous dyke (Stone et al. 2008). Data from this study, Mitchell et al. (1999) and Thistlewood et al. (1997).

Figure 5. Pyroxene end-member compositions represented in the quadrilateral system Enstatite 732 Ferrosilite - Wollastonite for Falkland Islands intrusions (this study and Mitchell et al. 1999) and dolerites from the Transantarctic Mountains (Elliot 1995; Demarchi et al. 2001). MFCT, 
747

748

749

750

751

752

753

754

755

756

757

758

759

760

761

762

763

764

Mount Fazio Chemical Type; SPCT, Scarab Peak Chemical Type; NVL, Northern Victoria Land.

Figure 6. Chondrite-normalized REE profiles for representative samples of a) DIT intrusions and b) PST, MAT and E-W intrusions.

Figure 7. a) to d) Multi-element ORB-normalized (Sun \& McDonough 1989) variation diagrams for Falkland Islands dykes. Comparable basalts from other regions of the low $\mathrm{TiO}_{2}$ Gondwana LIP are shown by grey lines. Sample SA.6.1 (South Africa), Riley et al. (2006); VF111-85, CT3 basalt, Dronning Maud Land (Luttinen \& Furnes 2000); 47206-3, low $\mathrm{TiO}_{2}$ tholeiite from Schirmacher Oasis, Dronning Maud Land (Sushchevskaya et al. 2009); Average MFCT from Elliot et al. (1995).

Figure 8. a) $\varepsilon_{\text {Ndd }} \mathrm{N}_{182}$ versus ${ }^{87} \mathrm{Sr} /{ }^{86} \mathrm{Sr}_{182}$; b) ${ }^{207} \mathrm{~Pb} /{ }^{204} \mathrm{~Pb}$ versus ${ }^{206} \mathrm{~Pb} /{ }^{204} \mathrm{~Pb}$ for Falkland Islands dykes. c) $\varepsilon \mathrm{Nd}_{182}$ versus ${ }^{207} \mathrm{~Pb} /{ }^{204} \mathrm{~Pb}$ for Falkland Islands intrusions. Symbols as for Fig. 4. Data sources this study, Mitchell et al. (1999) and Thistlewood et al. (1997).

Figure. 9 a) $\varepsilon \mathrm{Nd}_{182}$ versus $\mathrm{MgO}$; b) $\varepsilon \mathrm{Nd}_{182}$ versus $\mathrm{Th} / \mathrm{Ta}$ and c) ${ }^{87} \mathrm{Sr}^{86} \mathrm{Sr}_{182}$ versus $1 / \mathrm{Sr}$ for Falkland Islands intrusions. Symbols as for Fig. 4 except grey dots are for the lowest reported $\mathrm{Th} / \mathrm{Ta}$ for Ferrar dolerites (Fleming et al. 1995). Parameters for the AFC mixing line are given in Table 4 with $\%$ AFC given on the mixing line.

Figure 10. Ti/Zr versus $\mathrm{SiO}_{2}$ for Falkland Islands dykes. Symbols as for Fig. 4.

Figure 11. $\mathrm{TiO}_{2}$ versus $\mathrm{MgO}$, for Falkland Islands dykes the Ferrar LIP and igneous rocks considered to be transitional between the compositions of Ferrar and Karoo magmas. Data sources; Hergt et al. (1989), Brewer et al. (1992), Elliot et al. (1995), Fleming et al. (1995), Molzahn et al. (1996), Wilhelm \& Worner (1996), Antonini et al. (1999), Elliot et al. (1999), Elliot \& Fleming (2004), Riley et al. (2006). Falkland Islands samples symbols as for Fig. 4.

Fig. 12. $\varepsilon \mathrm{Nd}_{182}$ versus ${ }^{87} \mathrm{Sr}^{86}{ }^{8 \mathrm{Sr}_{182}}$ for Falkland Islands PST intrusions (filled dots) Karoo low $\mathrm{TiO}_{2}$ volcanic rocks (open circles), Dronning Maud Land CT1 (open triangles), CT2 (filled diamonds) and CT3 (filled triangles) basalts. Details of the parameters used in generating the three AFC mixing lines (CT1, PST-1 and PST-2) are given in Table 4. Each cross represents 1\% AFC. Data sources for Karoo Province; Galerne et al. (2008); McClintock et al. (2008); Neumann et al. (2011).

Figure 13. a) $\mathrm{CaO}$ versus $\mathrm{MgO}$ (weight \%) for Falkland Islands intrusions (black dots PST; grey dots, DIT; grey squares MAT; triangles, E-W) and Dronnning Maud Land high MgO, silica- 
oversaturated CT1 basalts (circles). The dividing line between melts derived from peridotite and pyroxenite sources is taken from Herzberg \& Asimow (2008). Lines with crosses and arrows represent the effect of accumulation of the phase indicated on the composition of PST basalt NEF9, with each cross representing 5\% accumulation. b) $\mathrm{Cr}$ (ppm) versus $\mathrm{SiO}_{2}$ for Falkland Islands intrusions (symbols as for Fig. 4) and high-Mg andesites from Mt Shasta (crosses; Baker et al. 1994).

Figure 14. Ti/Zr versus $\mathrm{SiO}_{2}$, for a) Karoo LIP volcanic rocks and b) Ferrar LIP volcanic rocks. Note that the KwaZulu-Natal and Theron Mountains low $\mathrm{TiO}_{2}$ samples are considered to be magma types transitional between Karoo and Ferrar types. Data sources; Transantarctic Mountains and Theron Mountains; Hergt et al. (1989), Brewer et al. (1992), Elliot et al. (1995), Fleming et al. (1995), Molzahn et al. (1996), Wilhelm \& Worner (1996), Antonini et al. (1999), Elliot et al. (1999), Elliot \& Fleming (2004). Karoo (including Dronning Maud Land) Luttinen et al. (1998), Luttinen \& Furnes (2000), Heinonen \& Luttinen (2008), Heinonen et al. (2010; 2013; 2014) Neumann et al. (2011). Kirwanveggan; Harris et al. (1990).

Figure 15. a) Olivine equilibration temperatures $\left({ }^{\circ} \mathrm{C}\right)$ versus $\mathrm{Mg} \#$ of liquid in equilibrium with olivine for Ahlmannryggen dykes (filled dots; Heinonen \& Luttinen 2008), Vestfjella high $\mathrm{TiO}_{2}$ ferropicrite (filled triangles; Heinonen et al. 2013), Etendeka picrite (open squares; Kieding et al. 2011) and Falklands Islands MAT intrusion (star in circle) and E-W intrusions (open triangles). Olivine equilibration temperatures have been calculated according to the scheme of Putirka et al. (2007). Vertical lines connecting points for Ahlmannryggen samples are calculated equilibration temperatures for different olivine phenocrysts in individual whole-rock samples. Figures in italics are $T_{P}$ from melt inclusions for Etendeka samples plotted in Fig. 15a (Kieding et al. 2011). b) Inferred temperature-pressure conditions at which fractional melting terminated for calculated primary magmas from Dronning Maud Land, the Karoo Province of southern Africa, Ferrar dolerites of Antarcitca and picrites of the Etendeka Province of western Africa. The diagram was constructed following the methods of Herzberg and Gazel (2009) with data for the Ferrar province and Iceland from Hole (2015). Samples with $\mathrm{MgO}>20$ weight \% are shown schematically following an adiabatic pathway for $T_{P}=1640^{\circ} \mathrm{C}$. The diagonally shaded box on the temperature axis is the range of olivine equilibration temperatures, calculated at 0 $\mathrm{GPa}$, for olivine in ferro-picrite dykes from Dronning Maud following the method of Putirka et al. (2007), and the box labelled 'MAT \& E-W' is the same calculations for MAT and E-W intrusions. Adiabatic melting paths are labelled with mantle potential temperature. $2 \sigma$ error bars are from Hole (2015). c) $\mathrm{T}_{\mathrm{P}}$ calculated from melt inclusions in ultra-magnesian olivines from the 
798 Etendeka Provice versus olivine equilibration temperatures for the same samples. Data from 799 Keiding et al. (2011).

800 


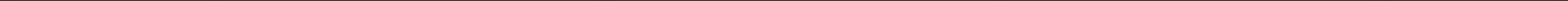




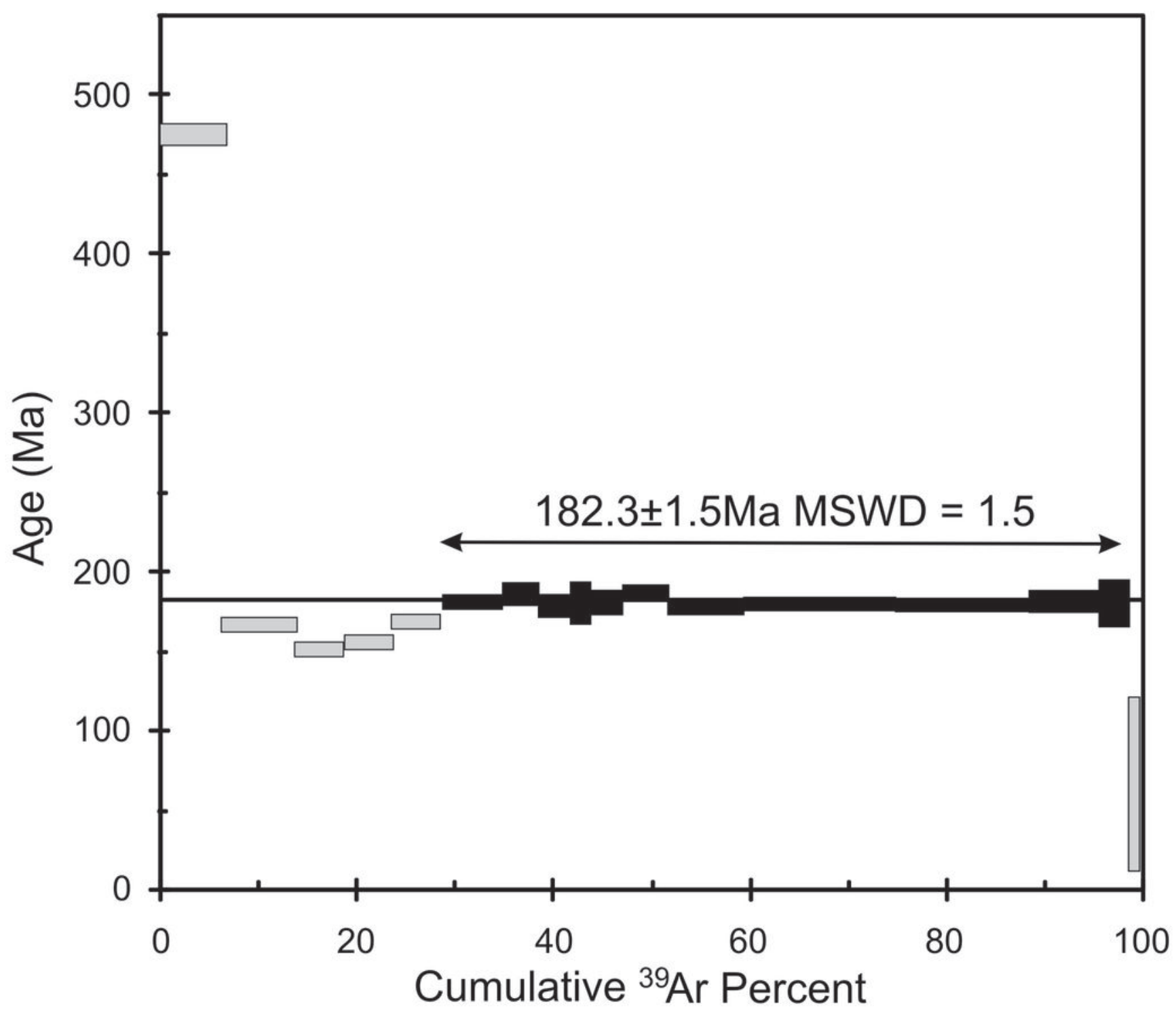



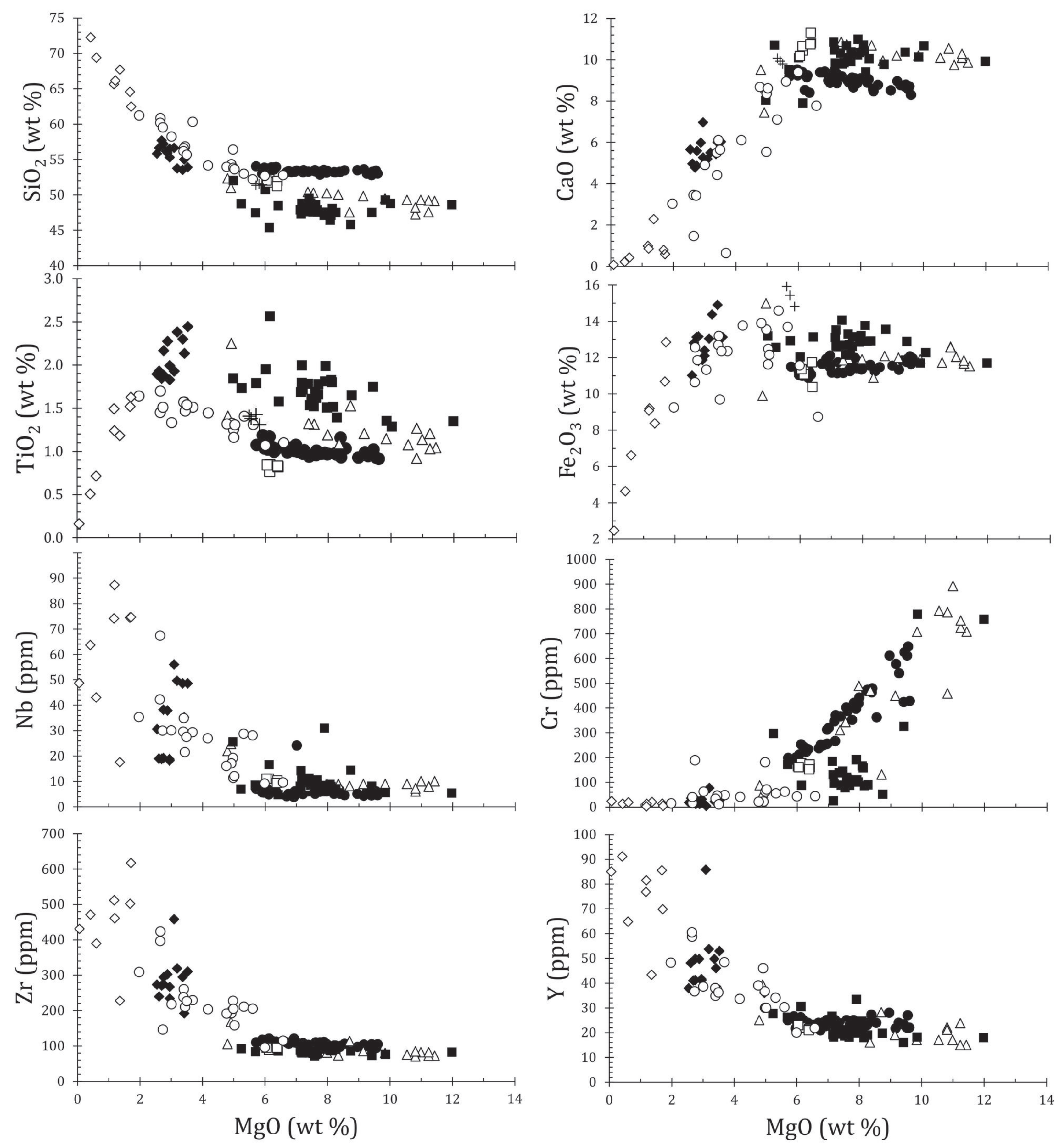

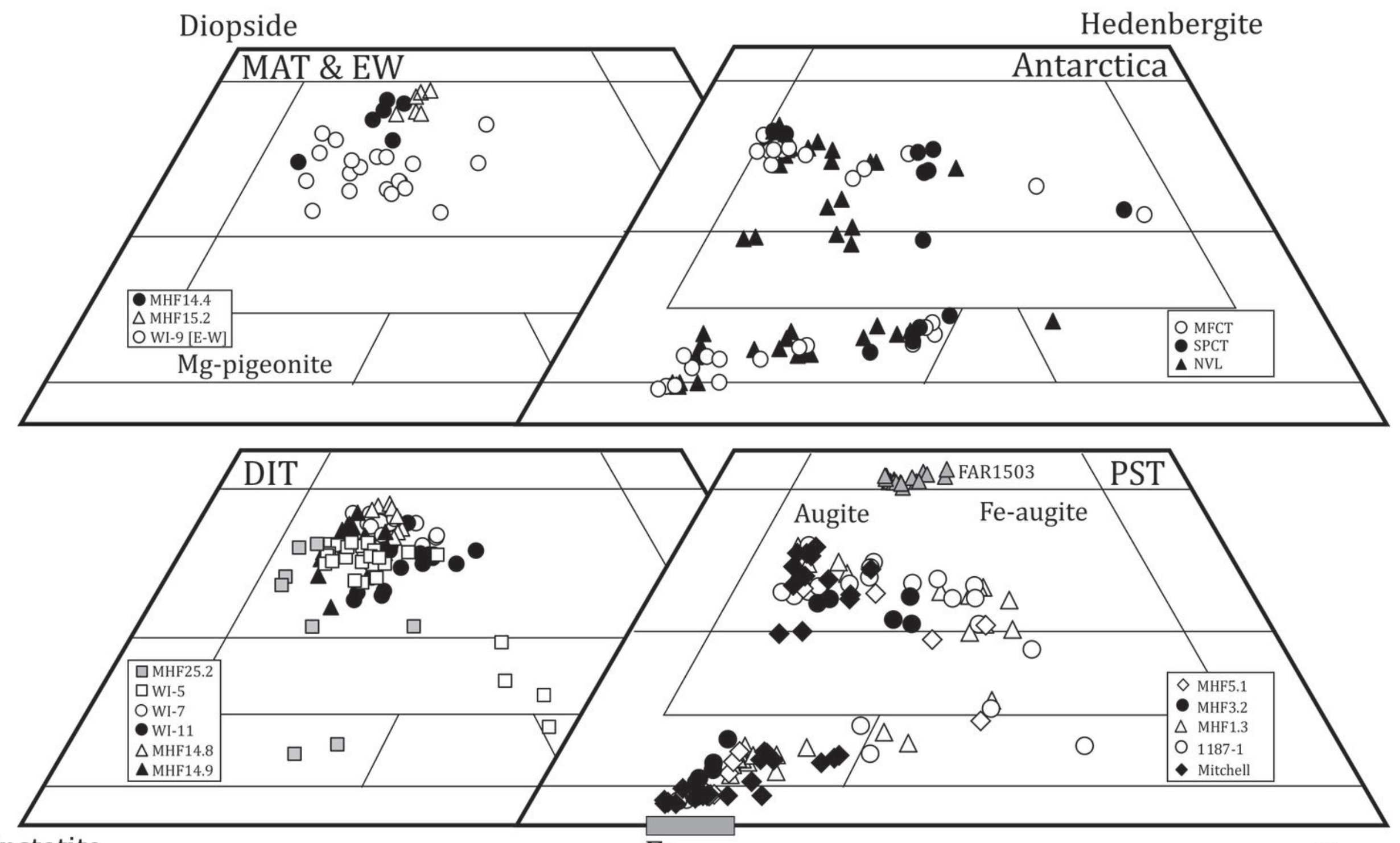

Ferrosilite 


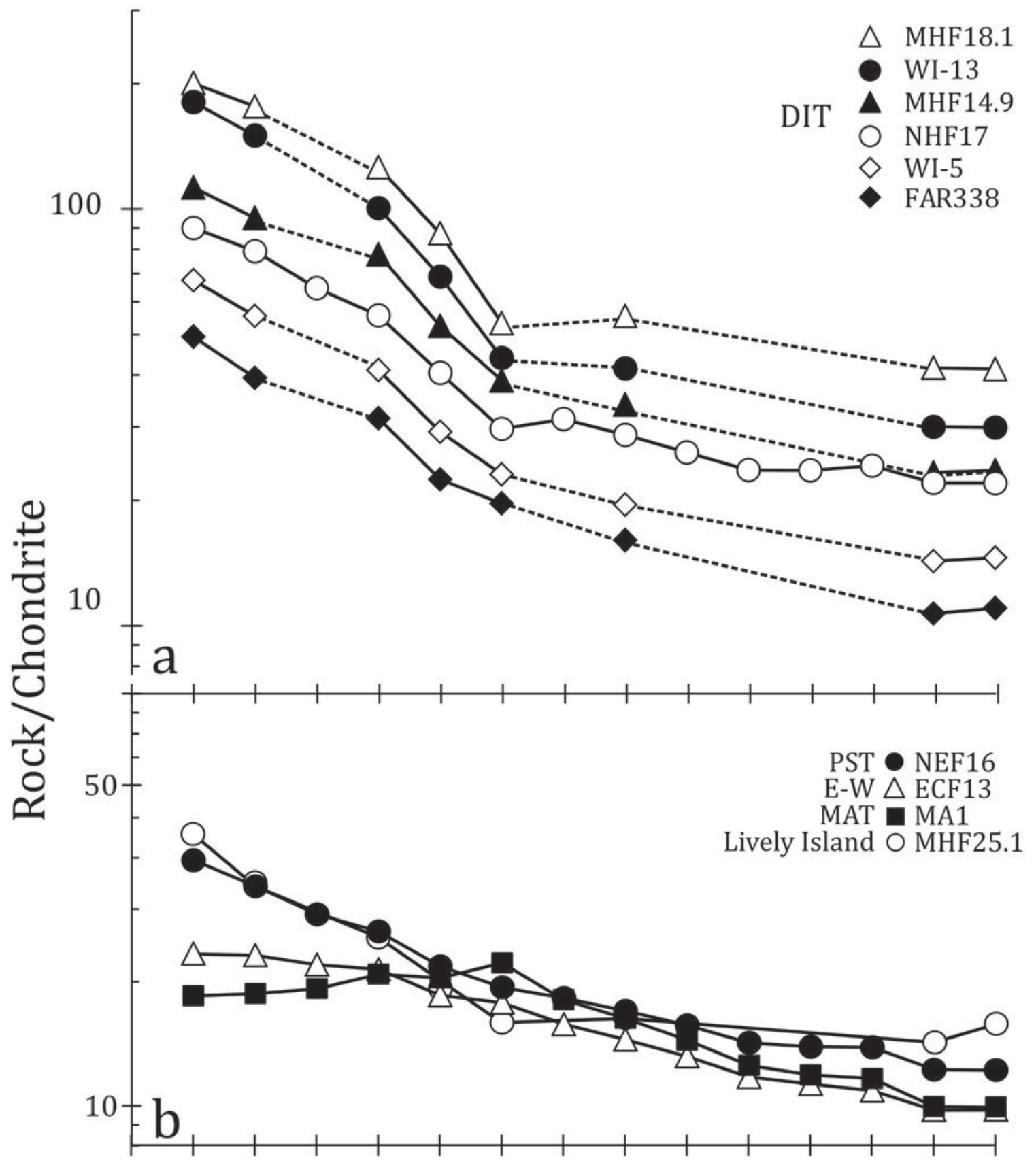

La Ce Pr Nd Sm Eu Gd Tb Dy Ho Er Tm Yb Lu 


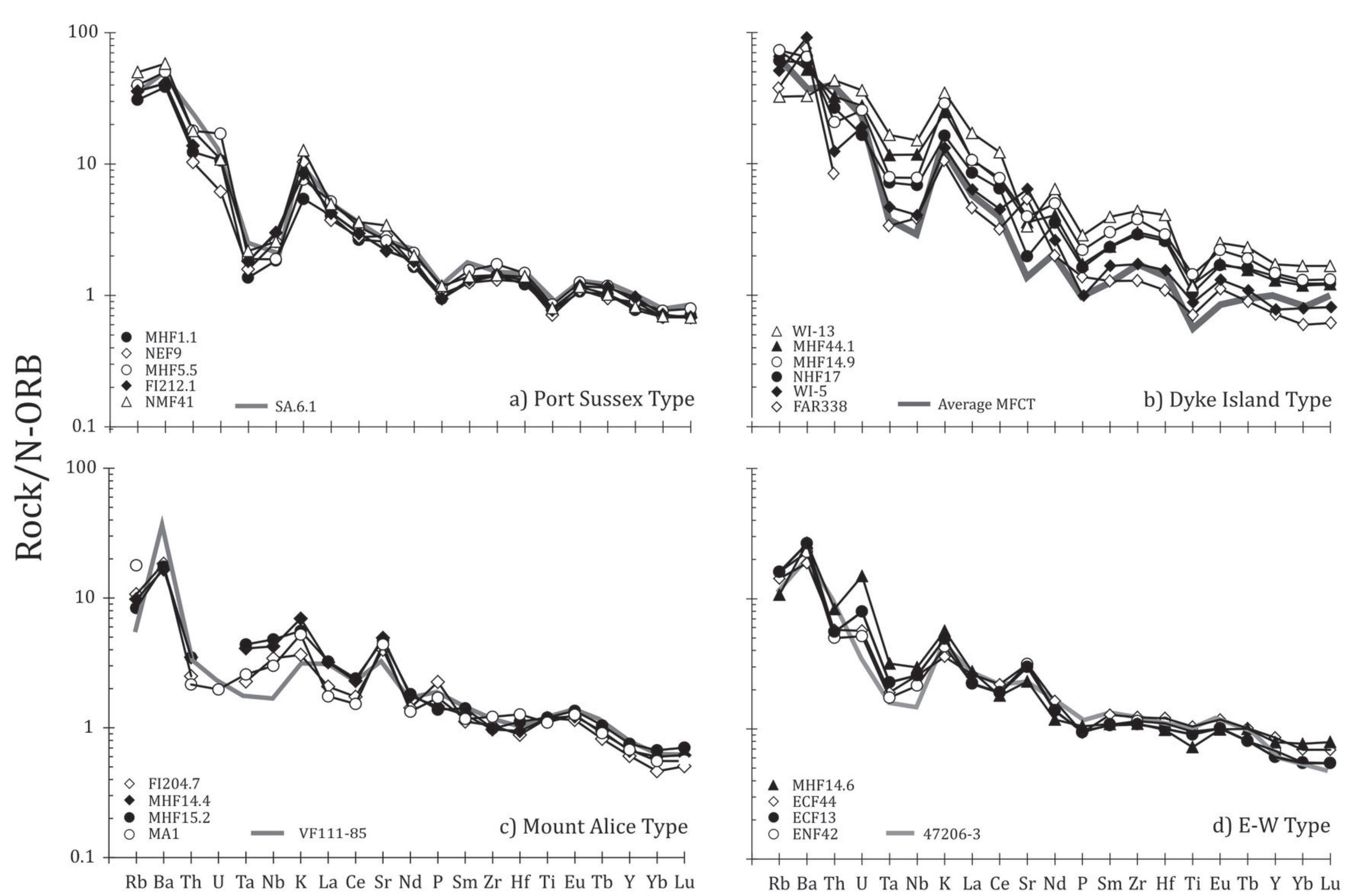



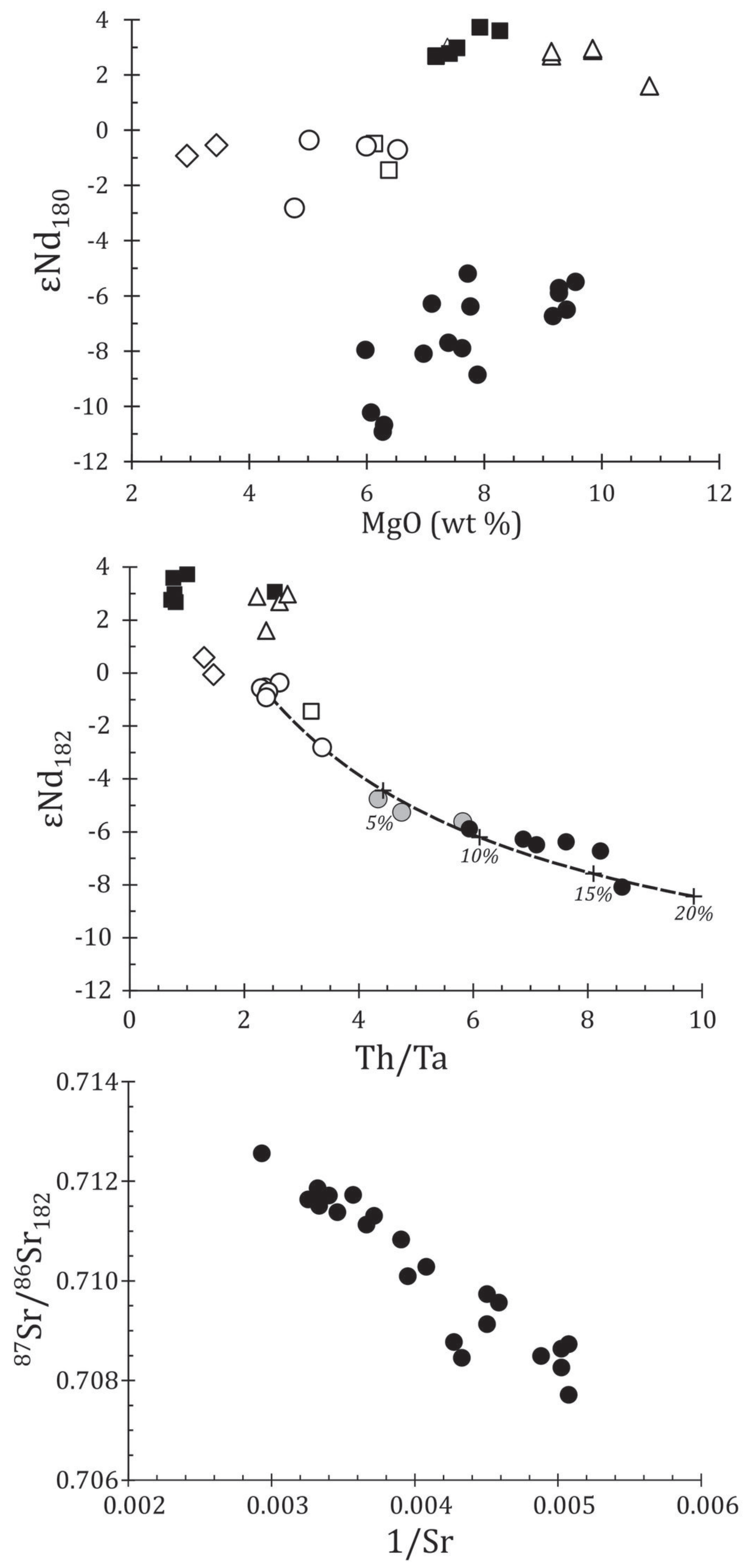


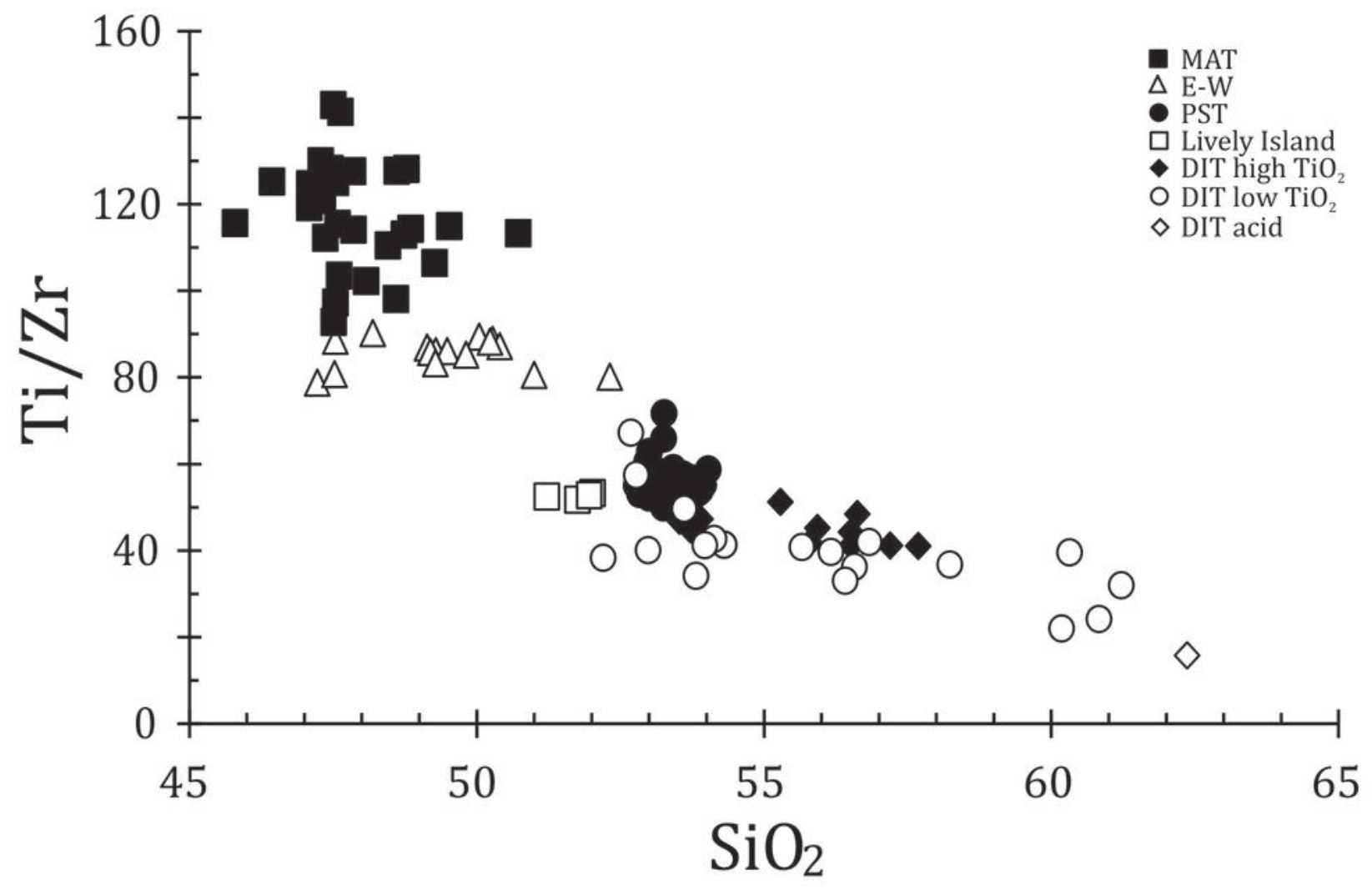




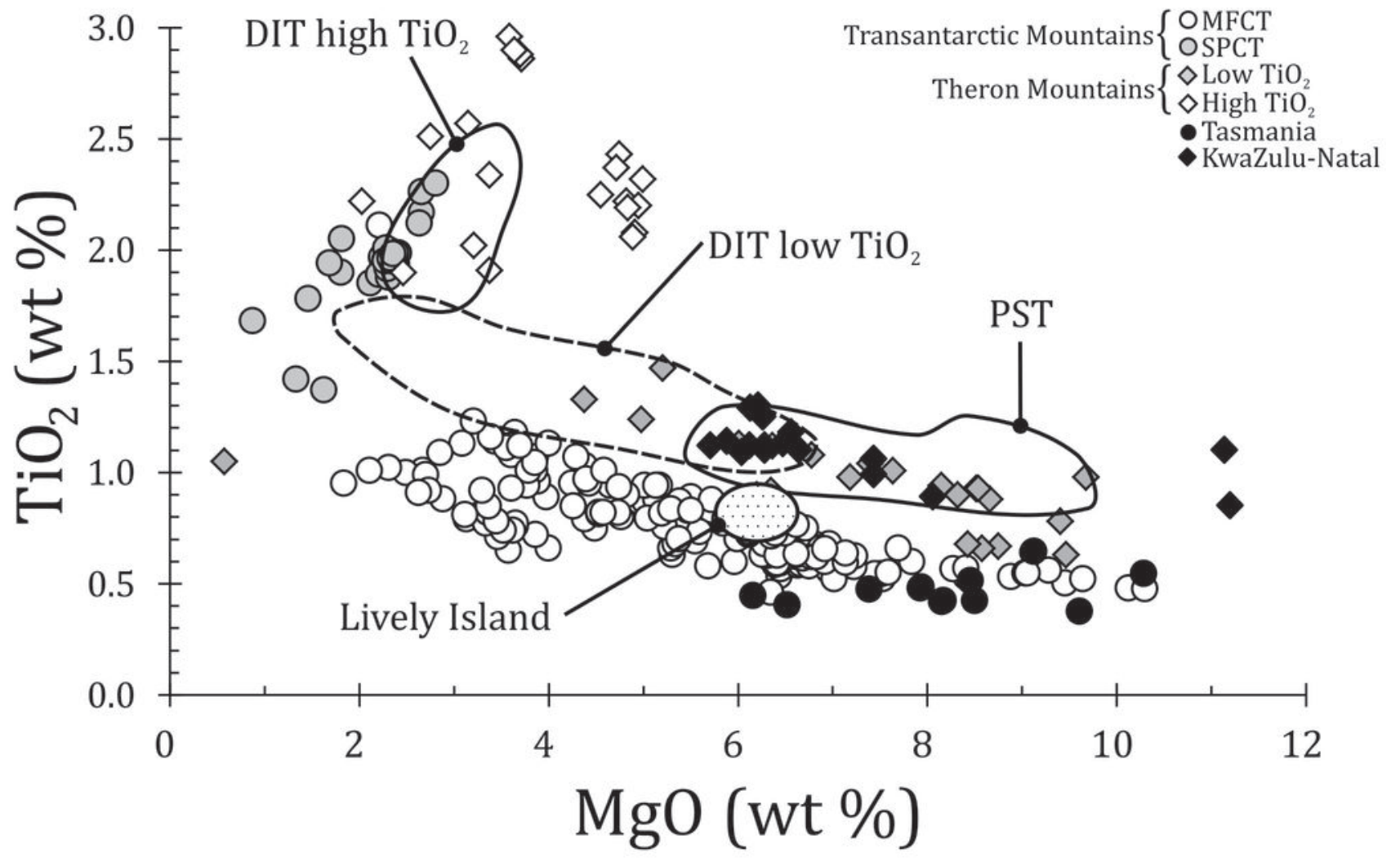




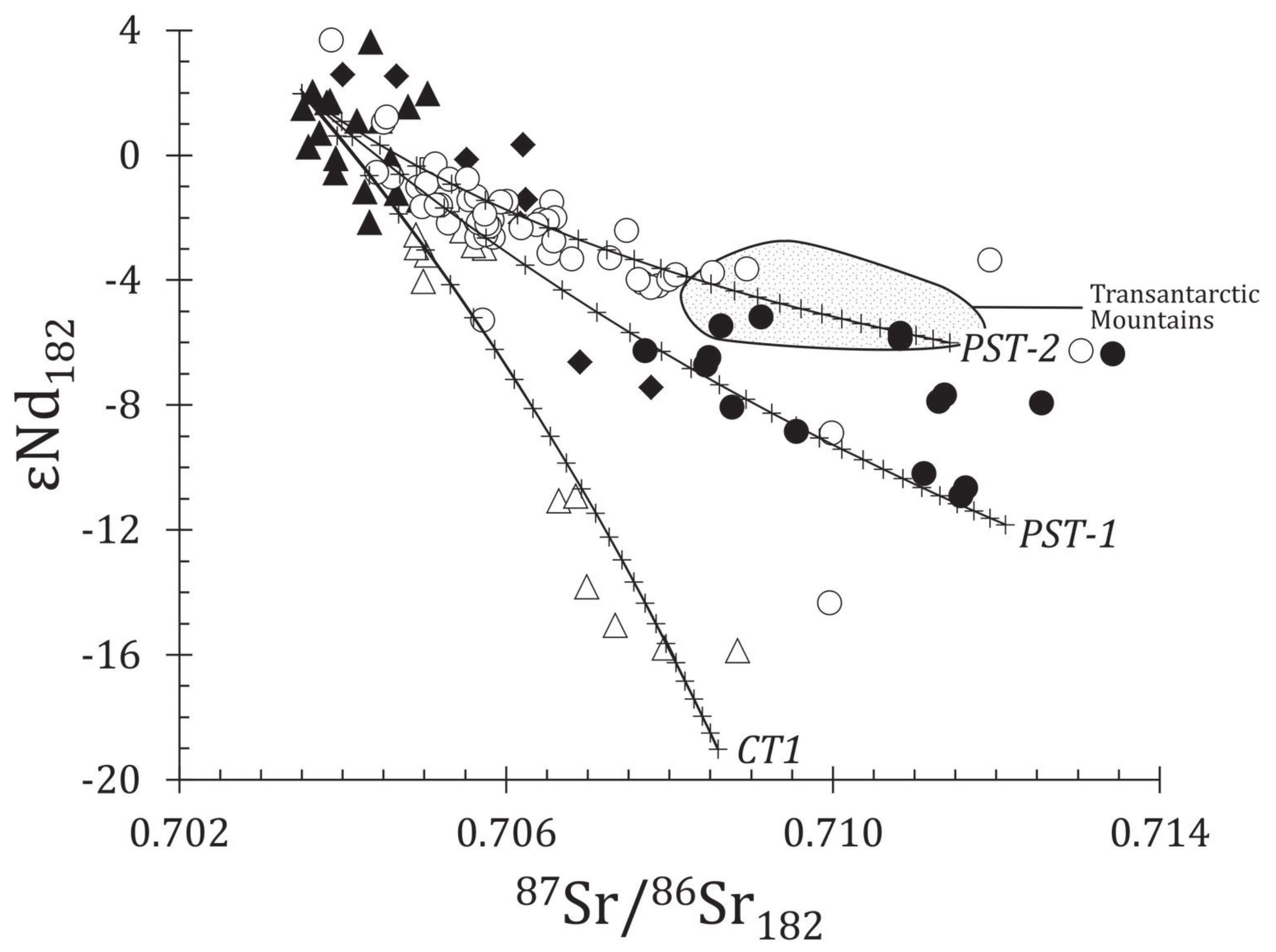



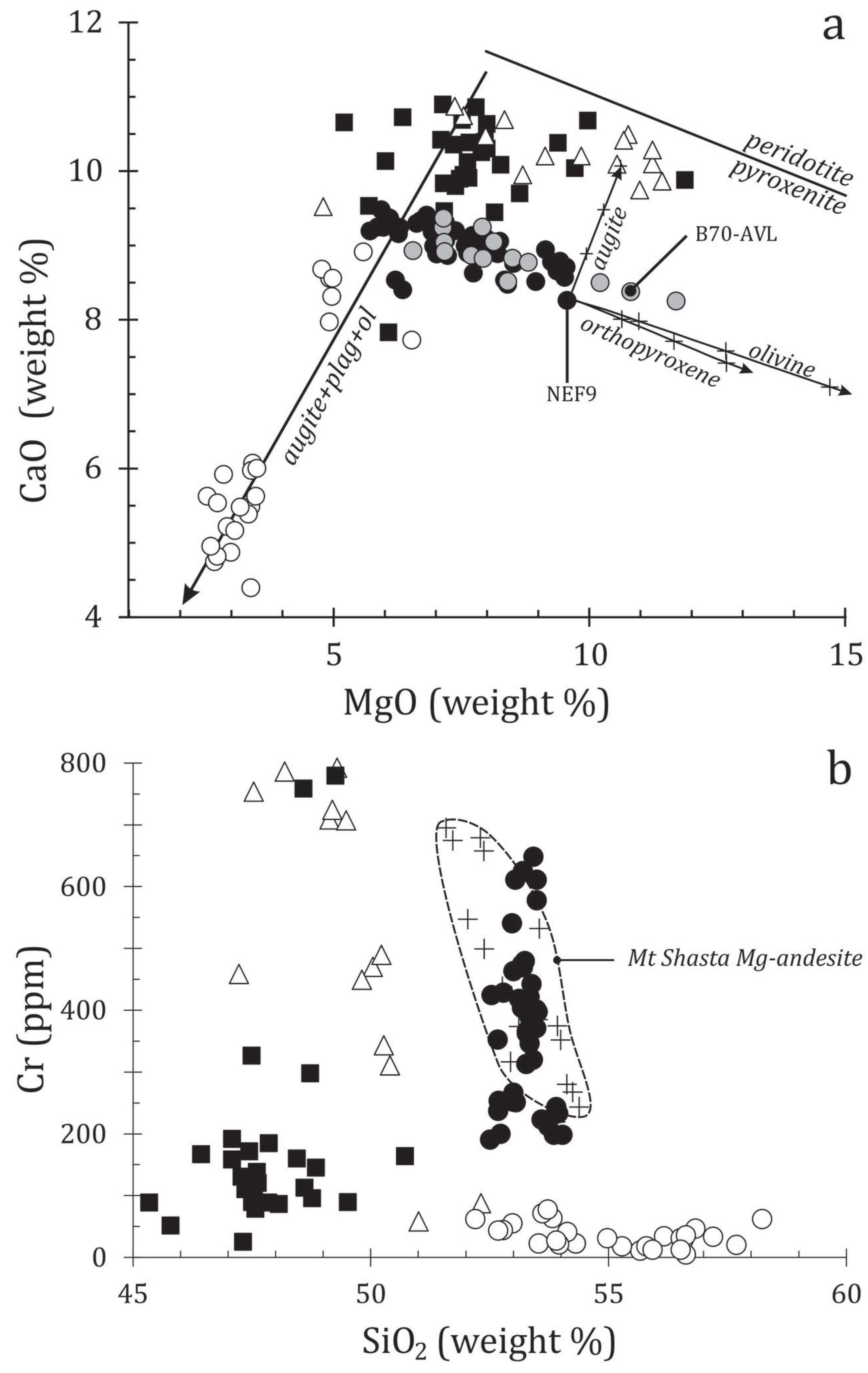


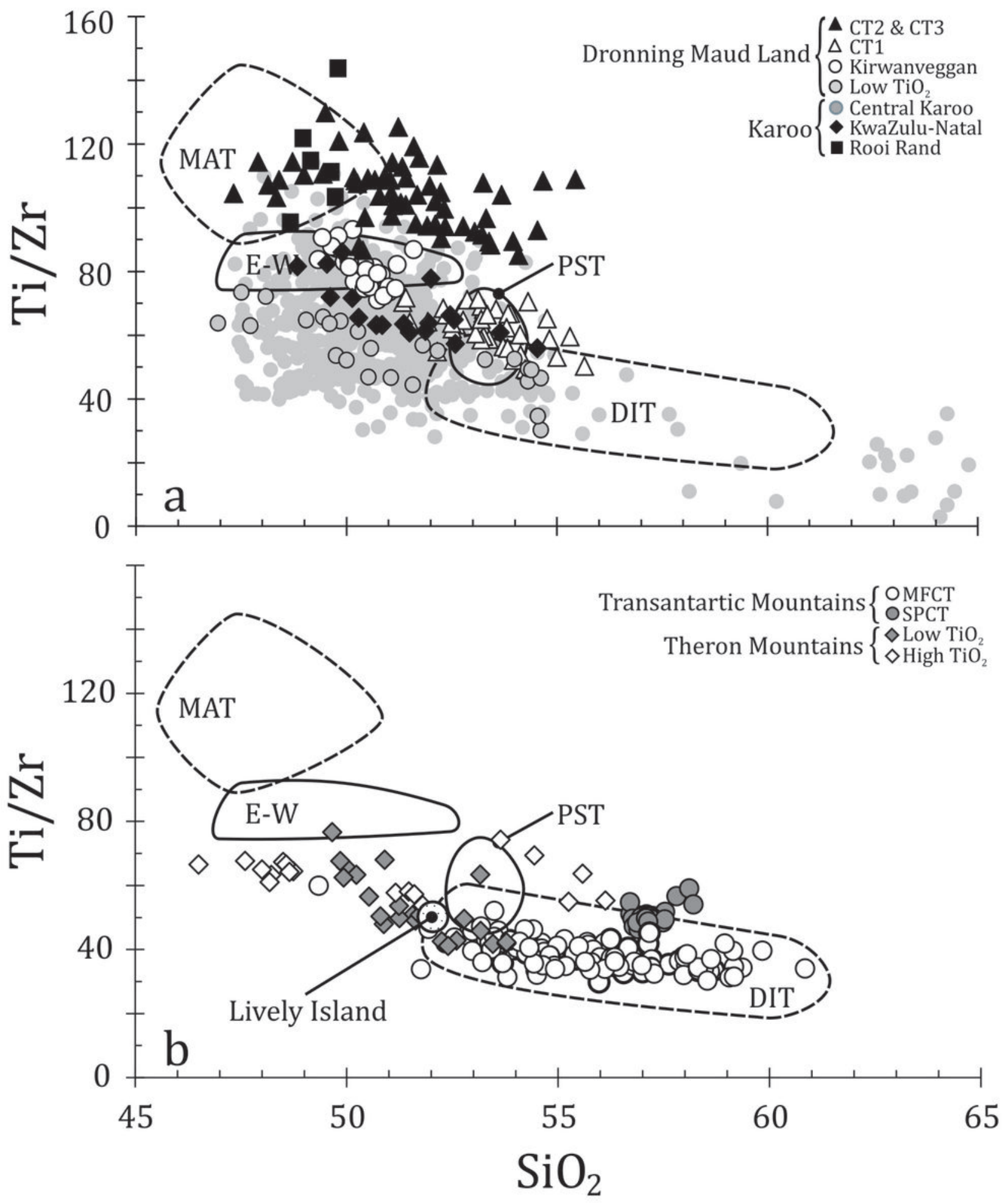




\begin{tabular}{|c|c|c|c|c|c|c|c|c|c|c|}
\hline Sample & $1187-1$ & $\# 1503$ & NEF9 & NMF41 & MHF1.1 & MHF5.5 & ECF13 & ECF42 & ECF44 & MHF14.6 \\
\hline Type & PST & PST & PST & PST & PST & PST & EW & EW & EW & EW \\
\hline$\overline{\mathrm{SiO}_{2}}$ & 52.67 & 53.20 & 52.41 & 53.59 & 53.49 & 53.01 & 49.49 & 49.82 & 50.40 & 47.02 \\
\hline $\mathrm{TiO}_{2}$ & 0.97 & 1.02 & 0.89 & 1.02 & 0.99 & 1.07 & 1.15 & 1.21 & 1.32 & 0.92 \\
\hline $\mathrm{Al}_{2} \mathrm{O}_{3}$ & 14.00 & 12.90 & 15.69 & 14.87 & 13.15 & 13.90 & 14.30 & 14.47 & 15.22 & 14.79 \\
\hline $\mathrm{Fe}_{2} \mathrm{O}_{3}$ & 11.94 & 11.90 & 11.50 & 11.25 & 11.29 & 12.03 & 11.91 & 11.99 & 11.85 & 12.54 \\
\hline $\mathrm{MnO}$ & 0.14 & 0.14 & 0.13 & 0.17 & 0.13 & 0.16 & 0.17 & 0.18 & 0.02 & 0.19 \\
\hline $\mathrm{MgO}$ & 7.74 & 9.43 & 5.96 & 6.29 & 9.15 & 6.93 & 9.85 & 9.14 & 7.38 & 10.77 \\
\hline $\mathrm{CaO}$ & 8.63 & 8.79 & 9.35 & 9.24 & 8.94 & 9.18 & 10.20 & 10.20 & 10.87 & 10.49 \\
\hline $\mathrm{K}_{2} \mathrm{O}$ & 2.45 & 1.90 & 2.61 & 2.52 & 2.10 & 2.52 & 2.47 & 2.58 & 2.57 & 2.33 \\
\hline $\mathrm{P}_{2} \mathrm{O}_{5}$ & 0.98 & 0.46 & 0.77 & 0.92 & 0.40 & 0.55 & 0.36 & 0.31 & 0.26 & 0.41 \\
\hline $\mathrm{Na}_{2} \mathrm{O}$ & 0.18 & 0.16 & 0.16 & 0.14 & 0.11 & 0.13 & 0.11 & 0.11 & 0.11 & 0.11 \\
\hline TOTAL & 99.70 & 99.90 & & & 99.75 & 99.48 & & & & 99.57 \\
\hline Loss & 1.50 & 0.50 & & & 1.26 & 2.62 & & & & 2.20 \\
\hline$\overline{\mathrm{Rb}}$ & 33.1 & 14.2 & 22 & 28 & 17 & 22 & 9 & 9 & 8 & 6 \\
\hline $\mathrm{Sr}$ & 533 & 205 & 256 & 307 & 232 & 234 & 269 & 282 & 283 & 208 \\
\hline $\mathrm{Nb}$ & 5.8 & 4.9 & 6 & 6 & 4.3 & 4.4 & 6 & 5 & 6 & 6.9 \\
\hline $\mathrm{Zr}$ & 110 & 93 & 97 & 106 & 104 & 113 & 80 & 85 & 91 & 81 \\
\hline Y & 23.9 & 23.1 & 25 & 23 & 22 & 25.1 & 17 & 19 & 24 & 22.1 \\
\hline $\mathrm{Cr}$ & 352 & 625 & 589 & 223 & 577 & 255 & 707 & 449 & 310 & 458 \\
\hline $\mathrm{Ni}$ & 100 & 170 & 133 & 75 & 146 & 91 & 236 & 174 & 113 & 254 \\
\hline $\mathrm{Ba}$ & nd & nd & 1235 & 365 & 250 & 316 & 167 & 144 & 126 & 208 \\
\hline $\mathrm{La}$ & 11.6 & 9.3 & 9.35 & 12.42 & 10.10 & 12.90 & 5.54 & 5.60 & 6.55 & 6.9 \\
\hline $\mathrm{Ce}$ & 25.1 & 20.1 & 20.87 & 27.19 & 19.90 & 24.90 & 14.19 & 14.29 & 16.48 & 13.5 \\
\hline $\operatorname{Pr}$ & & & 2.77 & 3.44 & & & 2.09 & 2.10 & 2.45 & \\
\hline $\mathrm{Nd}$ & 14.7 & 12.3 & 12.37 & 14.64 & 12.00 & 15.3 & 10.01 & 10.16 & 11.95 & 8.6 \\
\hline $\mathrm{Sm}$ & 3.58 & 3.15 & 3.29 & 3.68 & 3.34 & 4.06 & 2.80 & 2.84 & 3.37 & 2.87 \\
\hline $\mathrm{Eu}$ & 1.22 & 1.05 & 1.12 & 1.19 & 1.09 & 1.28 & 1.03 & 1.03 & 1.20 & 1.01 \\
\hline $\mathrm{Gd}$ & & & 3.76 & 4.16 & & & 3.25 & 3.29 & 4.10 & \\
\hline $\mathrm{Tb}$ & 0.72 & 0.63 & 0.64 & 0.68 & 0.77 & 0.79 & 0.54 & 0.54 & 0.68 & 0.67 \\
\hline Dy & & & 3.98 & 4.20 & & & 3.35 & 3.35 & 4.42 & \\
\hline Ho & & & 0.80 & 0.83 & & & 0.66 & 0.67 & 0.85 & \\
\hline $\mathrm{Er}$ & & & 2.30 & 2.37 & & & 1.87 & 1.90 & 2.41 & \\
\hline $\mathrm{Tm}$ & & & 0.35 & 0.36 & & & 0.28 & 0.28 & 0.36 & \\
\hline $\mathrm{Yb}$ & 2.14 & 1.93 & 2.08 & 2.12 & 2.09 & 2.33 & 1.66 & 1.68 & 2.11 & 2.34 \\
\hline $\mathrm{Lu}$ & 0.33 & 0.28 & 0.31 & 0.31 & 0.32 & 0.36 & 0.25 & 0.25 & 0.31 & 0.36 \\
\hline Th & 1.83 & 1.35 & 1.24 & 2.14 & 1.48 & 2.15 & 0.67 & 0.60 & 0.69 & 1.0 \\
\hline $\mathrm{U}$ & 0.80 & 0.50 & 0.29 & 0.51 & 0.5 & 0.8 & 0.37 & 0.24 & 0.27 & 0.7 \\
\hline $\mathrm{Ta}$ & 0.24 & 0.19 & 0.21 & 0.29 & 0.18 & 0.25 & 0.30 & 0.23 & 0.25 & 0.42 \\
\hline Hf & 2.73 & 2.33 & 2.6 & 2.86 & 2.49 & 3.03 & 2.05 & 2.27 & 2.48 & 2.01 \\
\hline $\mathrm{Pb}$ & & & 5.55 & 4.93 & & & 2.19 & 2.65 & 2.65 & \\
\hline Cs & 0.42 & 0.29 & & & 2.24 & 0.74 & & & & 0.3 \\
\hline Co & 43.30 & 47.30 & & & 50.8 & 42.9 & & & & 61.4 \\
\hline $\mathrm{Sc}$ & 25.70 & 26.60 & & & 27.8 & 28.2 & & & & 35 \\
\hline $\begin{array}{l}{ }^{87} \mathrm{Sr} /{ }^{86} \mathrm{Sr} \\
\pm 2 \mathrm{SE}\end{array}$ & $\begin{array}{r}0.71448 \\
\pm 1\end{array}$ & $\begin{array}{r}0.70900 \\
\pm 2\end{array}$ & & & $\begin{array}{r}0.70900 \\
\pm 18\end{array}$ & $\begin{array}{r}0.70948 \\
\pm 17\end{array}$ & & & & $\begin{array}{r}0.70600 \\
\pm 2\end{array}$ \\
\hline${ }^{87} \mathrm{Sr} /{ }^{86} \mathrm{Sr}_{182}$ & 0.71343 & 0.70848 & 0.71083 & & 0.70845 & 0.70877 & 0.70579 & 0.70376 & 0.70355 & 0.70578 \\
\hline${ }^{143} \mathrm{Nd} /{ }^{144} \mathrm{Nd}$ & 0.512252 & 0.512255 & & & 0.512259 & 0.512181 & & & & 0.512726 \\
\hline $\pm 2 \mathrm{SE}$ & \pm 7 & \pm 5 & & & \pm 6 & \pm 6 & & & & \pm 7 \\
\hline${ }^{143} \mathrm{Nd} /{ }^{144} \mathrm{Nd}_{182}$ & 0.512069 & 0.512063 & 0.512367 & & 0.51205 & 0.511981 & 0.512561 & 0.512551 & 0.512565 & 0.512475 \\
\hline$\varepsilon \mathrm{Nd}_{182}$ & -6.4 & -6.5 & -5.7 & & -6.7 & -8.1 & 2.9 & 2.7 & 3.0 & 1.6 \\
\hline${ }^{206} \mathrm{~Pb} /{ }^{204} \mathrm{~Pb}$ & & $17.826 \pm 11$ & 17.86 & & $18.394 \pm 8$ & $18.057 \pm 7$ & & 18.21 & & $18.474 \pm 7$ \\
\hline${ }^{207} \mathrm{~Pb} /{ }^{204} \mathrm{~Pb}$ & & $15.622 \pm 8$ & 15.61 & & $15.658 \pm 8$ & $15.643 \pm 8$ & & 15.47 & & $15.561 \pm 8$ \\
\hline${ }^{208} \mathrm{~Pb} /{ }^{204} \mathrm{~Pb}$ & & $38.044 \pm 19$ & 37.97 & & $38.143 \pm 20$ & $38.246 \pm 16$ & & 37.58 & & $38.111 \pm 15$ \\
\hline Sample & $1187-1$ & \#1503 & NEF9 & NMF41 & MHF1.1 & MHF5.5 & ECF13 & ECF42 & ECF44 & MHF14.6 \\
\hline
\end{tabular}




\begin{tabular}{|c|c|c|c|c|c|c|c|c|c|c|}
\hline Sample & MHF25.1 & FAR338 & WI-5 & MHF18.3 & NHF17 & MHF14.9 & MHF44.1 & WI-3 & MHF18.1 & MHF41.3 \\
\hline Type & Lively & DIT & DIT & DIT & DIT & DIT & DIT Acid & DIT Acid & DIT Acid & DIT Acid \\
\hline $\mathrm{SiO}_{2}$ & 51.76 & 52.41 & 52.44 & 53.24 & 53.97 & 56.06 & 55.49 & 60.88 & 64.11 & 68.92 \\
\hline $\mathrm{TiO}_{2}$ & 0.82 & 0.89 & 1.10 & 1.30 & 1.32 & 1.81 & 1.54 & 1.63 & 1.51 & 0.71 \\
\hline $\mathrm{Al}_{2} \mathrm{O}_{3}$ & 15.94 & 15.69 & 19.53 & 15.01 & 13.27 & 14.30 & 15.28 & 15.24 & 15.96 & 15.03 \\
\hline $\mathrm{Fe}_{2} \mathrm{O}_{3}$ & 10.33 & 11.5 & 8.66 & 12.05 & 13.88 & 12.28 & 12.31 & 9.19 & 10.61 & 6.57 \\
\hline $\mathrm{MnO}$ & 0.13 & 0.13 & 0.12 & 0.12 & 0.22 & 0.18 & 0.22 & 0.12 & 0.06 & 0.10 \\
\hline $\mathrm{MgO}$ & 6.38 & 5.96 & 6.54 & 4.99 & 4.77 & 2.93 & 3.48 & 1.96 & 1.67 & 0.60 \\
\hline $\mathrm{CaO}$ & 11.27 & 9.35 & 7.73 & 8.56 & 8.68 & 5.22 & 5.63 & 3.01 & 0.75 & 0.40 \\
\hline $\mathrm{K}_{2} \mathrm{O}$ & 2.46 & 2.61 & 2.92 & 3.21 & 2.52 & 4.10 & 3.76 & 5.74 & 3.25 & 3.51 \\
\hline $\mathrm{P}_{2} \mathrm{O}_{5}$ & 0.73 & 0.77 & 0.22 & 0.66 & 1.18 & 2.06 & 1.78 & 1.10 & 0.75 & 3.29 \\
\hline $\mathrm{Na}_{2} \mathrm{O}$ & 0.17 & 0.16 & 0.11 & 0.17 & 0.19 & 0.25 & 0.20 & 0.59 & 0.69 & 0.21 \\
\hline TOTAL & 99.63 & 99.49 & 99.36 & 99.30 & & 99.20 & 99.69 & 99.45 & 99.36 & 99.34 \\
\hline Loss & 1.88 & 2.10 & 3.28 & 3.64 & & 4.12 & 1.56 & 2.81 & 3.30 & 3.44 \\
\hline $\mathrm{Rb}$ & 10.9 & 21.7 & 29 & 17.6 & 34 & 40.8 & 40 & 18.2 & 20.5 & 59.6 \\
\hline $\mathrm{Sr}$ & 231 & 493.3 & 582 & 367 & 178 & 358 & 324 & 302 & 1204 & 715 \\
\hline $\mathrm{Nb}$ & 10.3 & 9.1 & 9.5 & 12.0 & 16 & 18.2 & 27.4 & 35.2 & 74.4 & 72 \\
\hline $\mathrm{Zr}$ & 93 & 96 & 115 & 158 & 192 & 267 & 226 & 309 & 502 & 620 \\
\hline Y & 21.4 & 20.0 & 21.8 & 30.0 & 39 & 41.1 & 36.2 & 48.2 & 85.5 & 64.8 \\
\hline $\mathrm{Cr}$ & 172 & 43 & 44 & 71 & 21 & 31 & 11 & 15 & 13 & 19 \\
\hline $\mathrm{Ni}$ & 63 & - & 7 & 95 & 10 & 20 & 6 & 2.0 & 8 & 2.0 \\
\hline $\mathrm{Ba}$ & 205 & 494 & 153 & 199 & 371 & 1409 & 528 & 207 & 2939 & 862 \\
\hline $\mathrm{La}$ & 10.8 & 11.7 & 16.0 & 15.7 & 21.36 & 26.7 & 27.0 & 42.8 & 47.5 & 68.9 \\
\hline $\mathrm{Ce}$ & 21.3 & 24.1 & 33.9 & 32.6 & 48.50 & 58.3 & 55.6 & 91.9 & 108 & 140.0 \\
\hline $\operatorname{Pr}$ & & & & & 6.14 & & & & & \\
\hline $\mathrm{Nd}$ & 11.9 & 14.7 & 19.2 & 20.5 & 25.93 & 36.4 & 29.7 & 47.0 & 58.9 & 69.3 \\
\hline $\mathrm{Sm}$ & 2.9 & 3.39 & 4.41 & 5.32 & 6.12 & 7.92 & 6.18 & 10.4 & 13.2 & 13.60 \\
\hline $\mathrm{Eu}$ & 0.92 & 1.14 & 1.34 & 1.63 & 1.72 & 2.25 & 1.77 & 2.55 & 3.09 & 3.41 \\
\hline $\mathrm{Gd}$ & & & & & 6.46 & & & & & \\
\hline $\mathrm{Tb}$ & 0.61 & 0.60 & 0.73 & 0.94 & 1.07 & 1.27 & 1.04 & 1.55 & 2.07 & 2.06 \\
\hline Dy & & & & & 6.62 & & & & & \\
\hline Но & & & & & 1.34 & & & & & \\
\hline $\mathrm{Er}$ & & & & & 3.91 & & & & & \\
\hline $\mathrm{Tm}$ & & & & & 0.62 & & & & & \\
\hline $\mathrm{Yb}$ & 2.41 & 1.82 & 2.43 & 2.81 & 3.74 & 3.97 & 3.62 & 5.11 & 7.07 & 7.47 \\
\hline $\mathrm{Lu}$ & 0.4 & 0.28 & 0.37 & 0.44 & 0.0 .56 & 0.60 & 0.55 & 0.76 & 1.05 & 1.11 \\
\hline Th & 1.68 & 1.03 & 1.50 & 1.49 & 3.19 & 2.48 & 3.90 & 5.17 & 5.6 & 6.54 \\
\hline U & 0.8 & & 0.90 & 0.9 & 0.77 & 1.20 & 1.30 & 1.70 & 2.2 & 2.10 \\
\hline $\mathrm{Ta}$ & 0.53 & 0.45 & 0.62 & 0.57 & 0.95 & 1.04 & 1.54 & 2.19 & 4.32 & 4.47 \\
\hline $\mathrm{Hf}$ & 2.32 & 2.24 & 3.18 & 3.78 & 5.29 & 5.94 & 5.53 & 8.35 & 11.7 & 13.80 \\
\hline $\mathrm{Pb}$ & & & & & 13.83 & & & & & \\
\hline Cs & 0.47 & & 0.28 & 0.4 & & 0.56 & 0.38 & 0.20 & 0.3 & 0.20 \\
\hline $\mathrm{Co}$ & 39.3 & 21.5 & 23.20 & 50.6 & & 35.00 & 29.4 & 16.70 & 12.5 & 7.40 \\
\hline $\mathrm{Sc}$ & 37.4 & 17.1 & 18.80 & 15.8 & & 24.70 & 23.7 & 18.40 & 16.3 & 13.30 \\
\hline${ }^{87} \mathrm{Sr} /{ }^{86} \mathrm{Sr}$ & 0.70564 & $0.70771 \pm 1$ & 0.71042 & 0.70618 & & 0.70730 & 0.70730 & 0.71029 & 0.71720 & 0.71745 \\
\hline $\pm 2 \mathrm{SE}$ & \pm 15 & 1 & \pm 6 & \pm 17 & & \pm 17 & \pm 17 & \pm 23 & \pm 17 & \pm 14 \\
\hline${ }^{87} \mathrm{Sr} /{ }^{86} \mathrm{Sr}_{182}$ & 0.70510 & 0.70733 & 0.71004 & 0.70581 & 0.70594 & 0.70554 & 0.70637 & 0.70983 & 0.71716 & 0.71714 \\
\hline${ }^{143} \mathrm{Nd} /{ }^{144} \mathrm{Nd}$ & 0.512505 & $0.512540 \pm$ & $0.512533 \pm 8$ & 0.512572 & & 0.512561 & 0.512561 & 0.512535 & 0.512595 & 0.512542 \\
\hline $\pm 2 \mathrm{SE}$ & \pm 8 & 9 & & \pm 5 & & \pm 6 & \pm 6 & \pm 7 & \pm 7 & \pm 7 \\
\hline${ }^{143} \mathrm{Nd} /{ }^{144} \mathrm{Nd}_{182}$ & 0.512322 & 0.512374 & 0.51236 & 0.512377 & 0.512259 & 0.512349 & 0.512405 & 0.512369 & 0.512427 & 0.512398 \\
\hline$\varepsilon \mathrm{Nd}_{182}$ & -1.5 & -0.6 & -0.7 & -0.4 & -2.8 & -0.9 & 3.1 & -0.6 & 0.6 & -0.1 \\
\hline${ }^{206} \mathrm{~Pb} /{ }^{204} \mathrm{~Pb}$ & $18.781 \pm 9$ & $17.980 \pm 9$ & $18.067 \pm 9$ & $18.430 \pm 8$ & & & & $18.016 \pm 10$ & $18.326 \pm 8$ & $18.393 \pm 6$ \\
\hline${ }^{207} \mathrm{~Pb} /{ }^{204} \mathrm{~Pb}$ & $15.670 \pm 9$ & $15.510 \pm 8$ & $15.512 \pm 8$ & $15.633 \pm 7$ & & & & $15.508 \pm 10$ & $15.576 \pm 8$ & $15.529 \pm 6$ \\
\hline${ }^{208} \mathrm{~Pb} /{ }^{204} \mathrm{~Pb}$ & $38.300 \pm 23$ & $37.361 \pm 18$ & $37.425 \pm 12$ & $37.944 \pm 2$ & & & & $37.492 \pm 26$ & $37.880 \pm 20$ & $37.583 \pm 12$ \\
\hline
\end{tabular}




\begin{tabular}{|c|c|c|c|c|}
\hline Sample & MHF15.2 & MHF14.4 & MHF15.1 & MA1 \\
\hline Type & MAT & MAT & MAT & MAT \\
\hline $\mathrm{SiO}_{2}$ & 45.92 & 47.40 & 48.56 & 47.51 \\
\hline $\mathrm{TiO}_{2}$ & 1.81 & 1.52 & 1.71 & 1.39 \\
\hline $\mathrm{Al}_{2} \mathrm{O}_{3}$ & 15.70 & 16.39 & 16.71 & 16.45 \\
\hline $\mathrm{Fe}_{2} \mathrm{O}_{3}$ & 13.60 & 13.23 & 12.52 & 12.91 \\
\hline $\mathrm{MnO}$ & 0.16 & 0.17 & 0.21 & 0.20 \\
\hline $\mathrm{MgO}$ & 8.00 & 7.51 & 7.15 & 8.27 \\
\hline $\mathrm{CaO}$ & 10.59 & 10.65 & 9.80 & 10.05 \\
\hline $\mathrm{K}_{2} \mathrm{O}$ & 2.59 & 2.53 & 2.53 & 2.65 \\
\hline $\mathrm{P}_{2} \mathrm{O}_{5}$ & 0.30 & 0.05 & 0.17 & 0.38 \\
\hline $\mathrm{Na}_{2} \mathrm{O}$ & 0.20 & 0.17 & 0.19 & 0.20 \\
\hline TOTAL & 98.87 & 99.63 & 99.56 & \\
\hline Loss & 1.5 & 1.90 & 2.25 & \\
\hline $\mathrm{Rb}$ & 4.7 & 5.5 & 2.0 & 10 \\
\hline $\mathrm{Sr}$ & 424 & 444 & 381 & 396 \\
\hline $\mathrm{Nb}$ & 11.2 & 9.9 & 10.7 & 7 \\
\hline $\mathrm{Zr}$ & 80 & 79 & 80 & 90 \\
\hline $\mathrm{Y}$ & 21.1 & 18.6 & 18.2 & 19 \\
\hline $\mathrm{Cr}$ & 89 & 78 & 95 & 89 \\
\hline $\mathrm{Ni}$ & 119 & 102 & 121 & 116 \\
\hline $\mathrm{Ba}$ & 110 & 105 & 103 & 827 \\
\hline $\mathrm{La}$ & 8.1 & 8.0 & 7.9 & 4.37 \\
\hline $\mathrm{Ce}$ & 18.0 & 17.2 & 18.3 & 11.45 \\
\hline $\operatorname{Pr}$ & & & & 1.83 \\
\hline $\mathrm{Nd}$ & 13.3 & 12.8 & 13.8 & 9.73 \\
\hline $\mathrm{Sm}$ & 3.72 & 3.32 & 3.78 & 3.08 \\
\hline $\mathrm{Eu}$ & 1.38 & 1.25 & 1.42 & 1.29 \\
\hline Gd & & & & 3.72 \\
\hline $\mathrm{Tb}$ & 0.7 & 0.63 & 0.72 & 0.61 \\
\hline Dy & & & & 3.66 \\
\hline Ho & & & & 0.71 \\
\hline $\mathrm{Er}$ & & & & 1.97 \\
\hline $\mathrm{Tm}$ & & & & 0.30 \\
\hline $\mathrm{Yb}$ & 2.05 & 1.83 & 2.04 & 1.69 \\
\hline $\mathrm{Lu}$ & 0.32 & 0.28 & 0.33 & 0.23 \\
\hline Th & 0.42 & 0.42 & 0.48 & 0.26 \\
\hline $\mathrm{U}$ & & & & 0.09 \\
\hline $\mathrm{Ta}$ & 0.58 & 0.54 & 0.6 & 0.3 \\
\hline Hf & 2.28 & 1.94 & 2.26 & 2.60 \\
\hline $\mathrm{Pb}$ & & & & 1.07 \\
\hline Cs & 0.3 & 0.35 & 0.2 & \\
\hline $\mathrm{Co}$ & 48.2 & 42.60 & 49.3 & \\
\hline $\mathrm{Sc}$ & 28.9 & 25.40 & 28.6 & \\
\hline $\begin{array}{l}{ }^{87} \mathrm{Sr} /{ }^{86} \mathrm{Sr} \\
+2 \mathrm{SE}\end{array}$ & $\begin{array}{r}0.70400 \\
+14\end{array}$ & $0.70385 \pm 17$ & $\begin{array}{r}0.70342 \\
\pm 15\end{array}$ & \\
\hline${ }^{87} \mathrm{Sr}^{86} \mathrm{Sr}_{182}$ & 0.70392 & 0.70375 & 0.70338 & 0.70497 \\
\hline${ }^{143} \mathrm{Nd} /{ }^{144} \mathrm{Nd}$ & 0.512747 & 0.512743 & 0.512738 & \\
\hline $\pm 2 \mathrm{SE}$ & \pm 6 & \pm 17 & \pm 6 & \\
\hline${ }^{143} \mathrm{Nd} /{ }^{144} \mathrm{Nd}_{182}$ & 0.512537 & 0.512548 & 0.512532 & 0.512588 \\
\hline$\varepsilon \mathrm{Nd}_{182}$ & 2.8 & 3.0 & 2.7 & 3.6 \\
\hline${ }^{206} \mathrm{~Pb} /{ }^{204} \mathrm{~Pb}$ & $19.152 \pm 6$ & $17.858 \pm 7$ & $18.131 \pm 7$ & 17.91 \\
\hline${ }^{207} \mathrm{~Pb} /{ }^{204} \mathrm{~Pb}$ & $15.656 \pm 5$ & $15.476 \pm 6$ & $15.579 \pm 7$ & 15.50 \\
\hline${ }^{208} \mathrm{~Pb} /{ }^{204} \mathrm{~Pb}$ & $38.464 \pm 13$ & $37.425 \pm 18$ & $37.762 \pm 16$ & 37.57 \\
\hline
\end{tabular}

Table 1. Whole-rock major and trace element and isotopic compositions of Falkland Islands intrusions used in this study. Major elements and isotopic compositions for sample numbers starting with EC, NE, NH, NM and MA are from Mitchell et al. (1999) with addition trace elements from this study. See supplementary materials for analytical methods. 
Table 2. Geochemical, mineralogical and petrographical characteristics of the different groups of Falkland Islands intrusions.

\begin{tabular}{|c|c|c|c|c|c|c|c|c|c|c|c|c|c|}
\hline Type & \begin{tabular}{|l|} 
Type locality \\
\end{tabular} & Mitchell $^{1}$ & Stone $^{2}$ & \begin{tabular}{|l|} 
Petrographic features \\
\end{tabular} & Mineralogy & Subgroup & Mg\# & $\mathrm{SiO}_{2}$ & $\mathrm{TiO}_{2}$ & $\mathrm{Ti} / \mathrm{Zr}$ & $\mathrm{Zr} / \mathrm{Y}$ & ${ }^{87} \mathrm{Sr} /{ }^{86} \mathrm{Sr}_{182}$ & $\varepsilon \mathbf{N d}_{182}$ \\
\hline $\begin{array}{l}\text { Port Sussex Creek } \\
\text { (PST) }\end{array}$ & \begin{tabular}{|l} 
Port Sussex \\
$51^{\circ} 40^{\prime} 15^{\prime \prime} \mathrm{S}$ \\
$58^{\circ} 58^{\prime} 41^{\prime \prime} \mathrm{W}$ \\
\end{tabular} & N-S & NE-SW & $\begin{array}{l}\text { Coarse-grained } \\
\text { dolerite }\end{array}$ & $\begin{array}{l}\text { Pig } \pm \text { Opx }+ \\
\text { Aug } \\
\text { Rare Ol + Di }\end{array}$ & none & $48-58$ & $52-54$ & $0.9-1.2$ & $50-70$ & $3.6-5.3$ & $0.7077-0.7134$ & -5.5 to -10.9 \\
\hline E-W & \begin{tabular}{|l} 
Fox Bay West \\
$51^{\circ} 57^{\prime} 02^{\prime \prime} \mathrm{S}$ \\
$60^{\circ} 05^{\prime} 21^{\prime}$ W
\end{tabular} & E-W & E-W & $\begin{array}{l}\text { Coarse-grained olivine } \\
\text { dolerite }\end{array}$ & $\begin{array}{l}\text { Ol + Plag } \pm \\
\text { Aug }\end{array}$ & none & $42-64$ & $47-54$ & $1.0-1.9$ & $77-90$ & $3.2-4.8$ & $0.7036-0.7058$ & -0.4 to +3.0 \\
\hline Lively Island (LI) & \begin{tabular}{|l} 
Lively Island \\
$52^{\circ} 00^{\prime} 00^{\prime \prime} \mathrm{S}$ \\
$58^{\circ} 27^{\prime} 47^{\prime} \mathrm{W}$ \\
\end{tabular} & $\begin{array}{l}\text { Lively } \\
\text { Island }\end{array}$ & NE-SW & $\begin{array}{l}\text { Coarse-grained with } \\
\text { accessory biotite }\end{array}$ & $\begin{array}{l}\text { Ol + Plag + } \\
\text { Aug } \pm \text { rare } \\
\text { pigeonite }\end{array}$ & none & $48-52$ & $51-52$ & $0.8-0.9$ & 53 & $4.0-4.54$ & 0.7053 & -0.5 to -1.4 \\
\hline \multirow{3}{*}{ Dyke Island (DIT) } & \multirow{3}{*}{$\begin{array}{l}\text { Dyke Island } \\
\text { 5159'33” S } \\
60^{\circ} 52^{\prime} 50^{\prime \prime} \mathrm{W} \\
\end{array}$} & \multirow{3}{*}{ Not defined } & \multirow{3}{*}{$\begin{array}{l}\text { Radial } \\
\text { swarm }\end{array}$} & \multirow{3}{*}{$\begin{array}{l}\text { Fine-grained aphyric, } \\
\text { rarely plagioclase } \pm \\
\text { augite-phyric }\end{array}$} & \multirow{3}{*}{ Plag + Aug } & Acid & $<22$ & $62-75$ & $0.2-1.6$ & $<31$ & $5.0-8.8$ & \multirow{3}{*}{$0.7055-0.7098$} & \multirow{3}{*}{-2.8 to -0.5} \\
\hline & & & & & & Low $\mathrm{TiO}_{2}$ & $27-57$ & $52-61$ & $1.1-1.7$ & $24-67$ & $4.8-7.4$ & & \\
\hline & & & & & & High $\mathrm{TiO}_{2}$ & $41-51$ & $53-58$ & $>1.80$ & $25-53$ & $6.8-8.4$ & & \\
\hline Mount Alice (MAT) & \begin{tabular}{|l|} 
Mount Alice \\
$52^{\circ} 09$ '12” S \\
60³5'55” W
\end{tabular} & $\begin{array}{l}\text { Mount } \\
\text { Alice }\end{array}$ & $\begin{array}{l}\text { Radial } \\
\text { swarm }\end{array}$ & $\begin{array}{l}\text { Fine-grained } \\
\text { plagioclase } \pm \text { olivine } \\
\text { phyric }\end{array}$ & $\begin{array}{l}\text { Ol + Plag } \pm \\
\text { Aug }\end{array}$ & none & $44-64$ & $47-50$ & $1.3-1.9$ & $98-142$ & $3.2-5.2$ & 0.7031-0.7039 & 0.0 to +3.7 \\
\hline
\end{tabular}

1. Groups described by Mitchell et al. (1999); 2. Groups defined by Stone et al. (2009) 


\begin{tabular}{lrrr|rrr}
\multicolumn{6}{c}{ Calculated extract for fractionation of PST and E-W intrusions } \\
& \multicolumn{3}{c}{ PST } & \multicolumn{3}{c}{ E-W } \\
& NGF16 & MHF5.1 & Calc & ECF12 & ECF44 & Calc \\
\cline { 2 - 7 } $\mathrm{SiO}_{2}$ & 54.01 & 53.81 & 53.82 & 49.69 & 51.03 & 50.98 \\
$\mathrm{TiO}_{2}$ & 0.94 & 1.00 & 1.13 & 1.05 & 1.21 & 1.36 \\
$\mathrm{Al}_{2} \mathrm{O}_{3}$ & 13.20 & 14.97 & 15.02 & 13.30 & 15.21 & 15.20 \\
$\mathrm{FeO}$ & 10.60 & 10.62 & 10.60 & 10.51 & 11.11 & 11.06 \\
$\mathrm{MnO}$ & 0.20 & 0.17 & 0.18 & 0.17 & 0.17 & 0.21 \\
$\mathrm{MgO}$ & 9.67 & 6.78 & 6.78 & 11.62 & 6.71 & 6.70 \\
$\mathrm{CaO}$ & 8.81 & 9.50 & 9.49 & 9.81 & 11.51 & 11.50 \\
$\mathrm{Na}_{2} \mathrm{O}$ & 1.96 & 2.62 & 2.56 & 2.29 & 2.56 & 2.46 \\
$\mathrm{~K}_{2} \mathrm{O}$ & 0.48 & 0.42 & 0.56 & 0.32 & 0.39 & 0.39 \\
$\mathrm{P}_{2} \mathrm{O}_{5}$ & 0.12 & 0.11 & 0.15 & 0.11 & 0.11 & 0.13 \\
Extract & & & $\%$ & & & $\%$ \\
Olivine & $\mathrm{FO}_{83}$ & & 0.0 & & & 57.0 \\
Plagioclase & $\mathrm{An}_{70}$ & & 18.9 & & & 40.4 \\
Pyroxene & $\mathrm{En}_{71} \mathrm{Fs}_{19} \mathrm{Wo}_{9}$ & 74.7 & & & \\
Pyroxene & $\mathrm{En}_{51} \mathrm{Fs}_{13} \mathrm{Wo}_{33}$ & 6.4 & & & 2.6 \\
$\sum$ residuals & & & 0.127 & & & 0.038 \\
$\mathrm{~F}$ & & & 0.79 & & & 0.75
\end{tabular}


Table 4 AFC parameters for the trajectories shown in Fig. 12. $\mathrm{R}$ is the ratio of assimilated rock to crystal cumulate. A value appropriate for upper-crustal contamination has been used. $\mathrm{F}$ is the total amount of crystallization required to reach the most extreme composition on a particular trajectory. $\mathrm{T}_{\mathrm{CHUR}}$ is the Chondritic Uniform Reservoir model $\mathrm{Nd}$ age for the most extreme composition on a particular trajectory, in Ga.

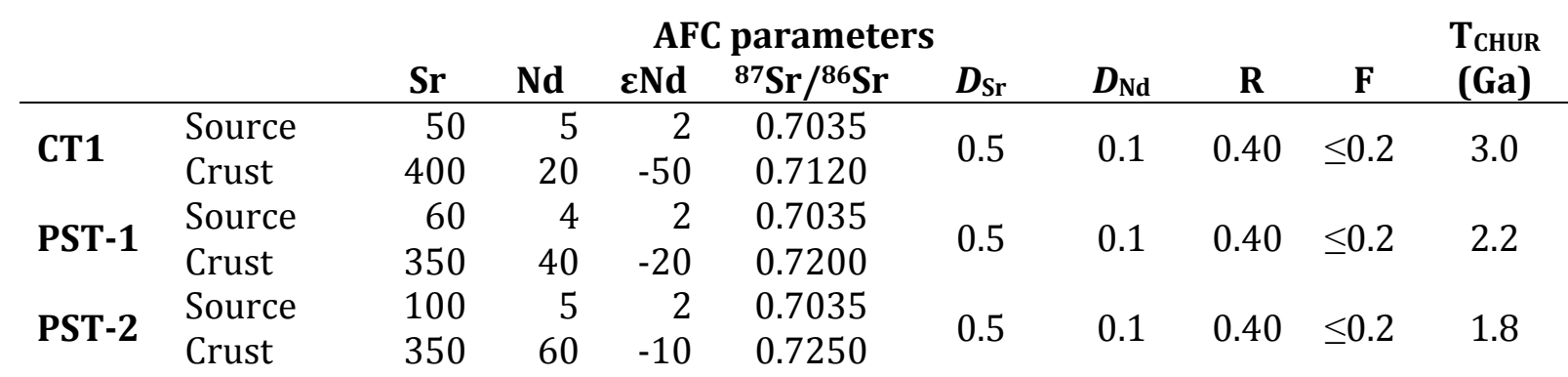

